\title{
Geochemistry and rare-metal bearing potentials of pegmatites of Gbugbu, Lema and Bishewa areas of North Central Nigeria
}

\author{
GARBA, A. Abdulrasaq ${ }^{1}$, ADEKEYE, Jacob I.D. ${ }^{2}$, AKANDE, S.O. ${ }^{2}$ and AJADI, Jimoh ${ }^{3 *}$. \\ 1 Nigerian Geological Survey Agency, Abuja. Nigeria \\ 2 Department of Geology and Mineral Sciences, University of Ilorin. Nigeria \\ 3 Department of Geology and Mineral Sciences, Kwara State University Malete. Nigeria
}

The authors acknowledge the immense supports received from the management of the Nigerian Geological Survey Agency (NGSA). Mr. Olufemi Ogedengbe, a retired Director of Economic Geology Department, NGSA was exceptionally supportive in all aspects of this research.

\begin{abstract}
The pegmatites of Gbugbu, Lema and Bishewa areas belong to the pegmatite belt of North-Central Nigeria which has been prospected for minerals since the early 1940's. Detailed geological mapping of the pegmatite bodies and sampling of muscovite extracts were carried out, while major, trace and rare earth elements geochemistry were achieved using ICP-OES and ICP-MS. Variation plots of major and trace elements were used to determine the geochemical characteristics of these pegmatite bodies. Structural features of the study area suggest fracture patterns in the Nigerian Basement rocks controlled the distribution of the pegmatites on a regional NW-SE, N-S and NE-SW and minor E-W trends. The pegmatites are peraluminous with major and trace elements pattern indicating similarities with granitic clan of igneous rocks. Qualitative assessment of the pegmatites using K/Rb vs $\mathrm{Cs}, \mathrm{K} / \mathrm{Cs}$ vs $\mathrm{Rb}, \mathrm{K} / \mathrm{Rb}$ vs $\mathrm{Rb} / \mathrm{Sr}$, variation plots suggest the majority of the pegmatites are mineralized with $\mathrm{Na} / \mathrm{K}$ ratio $>1$ and belong to the rare metal bearing class with a compositional variation suggesting regional zonation of the pegmatites. Furthermore, these plots suggest the Lema pegmatite field is highly evolved and belong to the LiBe-Ta Type (III) and Li-Cs-Be-Ta Type (IV) while majority of those in Gbugbu and Bishewa fields belong to the muscovite bearing Type (I) and Be bearing Type (II). It is concluded from this study that the pegmatites of Gbugbu, Lema and Bishewa pegmatite fields have the potentials for rare metal mineralization with alkali and rare alkali fractionation playing significant roles in the mineralization processes. Furthermore, field evidence and $\mathrm{Rb} v \mathrm{Vs}$ plot, suggests the pegmatites were emplaced at variable depths of between $20-30 \mathrm{~km}$ indicating that the Gbugbu and Bishewa pegmatite fields have been extensively eroded and are close to the roots of the primary mineralization exposing mainly the interior pegmatites of the Types I-II. On the other hand, the Lema field which suffered lesser degree of erosion has Type III-IV pegmatite still remaining at the center of a regionally zoned pegmatite body. The significance of this study is that the pegmatites of Gbugbu, Lema and Bishewa areas have potentials for economic mineralization of tantalite, wolframite, cassiterite and columbite.
\end{abstract}

Keywords: Pegmatites, Pnuematolysis, Albitization, Rare-metal, Mineralization, Peraluminous

DOI: $10.7176 / \mathrm{JEES} / 9-3-15$

Publication date:March $31^{\text {st }} 2019$

\section{Introduction}

The area of study is situated within two components 1:50,000 scale sheets 203 Lafiagi NW and NE and falls between latitudes $08^{\circ} 40^{\prime} 00^{\prime \prime} \mathrm{N}$ and $08^{\circ} 51^{\prime} 00^{\prime \prime} \mathrm{N}$ and longitudes $05^{\circ} 00^{\prime} 00^{\prime \prime} \mathrm{E}$ and $05^{\circ} 23^{\prime} 00^{\prime \prime} \mathrm{E}$ covering an area of approximately $840.5 \mathrm{Km}^{2}$ in Kwara State of West Central Nigeria. The Nigerian rare metal bearing pegmatites were hitherto believed to be concentrated in a $400 \mathrm{~km}$ long NE/SW trending belt (Jacobson and Webb 1946). However recent developments have shown that rare metal and gemstones bearing pegmatites are not restricted to a particular belt (Kuster, 1990; Matheis, 1991; Garba, 2003).

This paper examines the pegmatites around Gbugbu, Lema and Bishewa areas of North Central, Nigeria with emphasis on their distribution, geochemistry, petrochemical features and relationship with their host lithologies. The area of study has generated a lot of interests as a result of small-medium scale mining of rare metals and gemstones bearing pegmatites which has been taking place on the Patikiesin hills (Lema) and its environs. Since the 1940's, mining activities in the area still subsists albeit on small scale. Field observation in these areas indicated there is the dominance of rare metal and gemstone mineralization which show a progressive change in 
the mineralization type of the pegmatites from tin bearing greisens and pegmatites of Gbugbu Forest Reserve in the northeast to the microlite and tantalum bearing pegmatites of the Patikiesin hill towards a southwest transect to the tantalum, beryl and tourmaline bearing pegmatites of Bishewa, Ologomo and Share.

\section{Materials and Methods}

A total of 31 blocky white micas (muscovite extracts) from the intermediate and outer core zones of identified pegmatite bodies were collected using the method of Moller and Morteani, (1987a) and Preinfalk et al (2000). This involves selection of sample grains $>2 \mathrm{~mm}$ to avoid infiltration of secondary or altered muscovites. These samples are made up of 11 samples each from Gbugbu and Lema pegmatite fields, while 9 samples were obtained from Bishewa field.

Analyses of the samples were carried out by three methods after sample preparation and digestion. Trace elements and Rare Earth Elements concentrations were determined by Inductively Coupled Plasma Mass Spectrometry (ICP-MS) while the major oxides concentrations were determined by Inductively Coupled Plasma Optical Emission Spectrometry (ICP-OES). A total of three muscovite extract samples were dated for K/Ar mineral age (one sample from each of the pegmatite field) to determine their individual blocking ages and give an insight into the possible ages of the pegmatite body.

\section{Regional Geology}

Nigeria lies within the reactivated Pan African mobile belt which is situated between the West African craton in the west and the Congo craton in the east (figure 1a) and is underlain by the Precambrian Basement Complex rocks which were intruded by the Mesozoic Younger Granites and both overlain in part by the Cretaceous sediments (figure 1b). The Basement Complex rocks have been broadly divided into four lithological units namely (i) the migmatite-gneiss complex with ages ranging from Archean $(>3000 \mathrm{Ma})$ to upper Proterozoic $( \pm 2800 \mathrm{Ma})$ (Grant, 1971; Black, 1980; Rahaman, 1988; and Dada, 1998); (ii) the metavolcanosedimentary belts which are essentially made of schistose rocks of mostly greenschist facies of Proterozoic age (Rahaman et al., 1983; Odeyemi, 1988) (iii) the syntectonic to late tectonic granitoids of Precambrian to Lower Palaeozoic age (Pan African) which intrude both the migmatite-gneiss complex and the schist belt and (iv) unmetamorphosed dolerite dykes which are believed to be the youngest.

Pegmatite emplacement in Nigeria has been genetically linked to the suite of intrusive Pan African granitoids (Older Granites of the Nigerian Basement Complex) based on field relationships of Jacobson and Webb (1946). However, isotopic studies by Matheis and Caen-Vachette (1983) and Matheis (1987) suggest derivation of rare metal pegmatites of southwest Nigeria from reactivation of ancient lineaments, partial melting and external fluid supply. The Pan African in Nigeria was followed by conjugate strike slip fault systems which average in the NESW (NNE-SSW) and NW-SE (NNW-SSE) direction. These fault systems also show sinistral and dextral sense of displacement which cut across the earlier Pan African structures (McCurry, 1971; Wright, 1976 and Ball 1980).

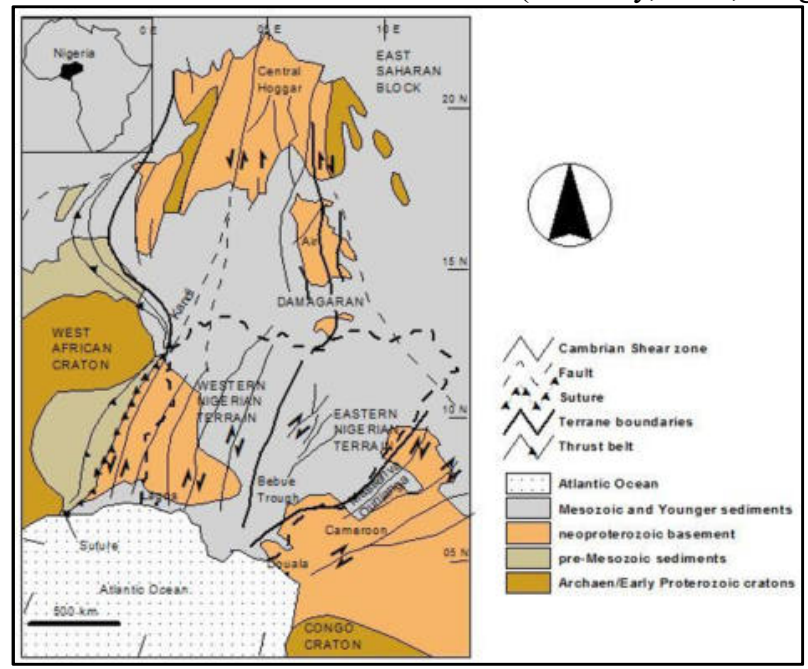

Figure 1a: Regional geological setting of West Africa showing the Hoggar-Air-Nigeria province within the

Late Proterozoic - Early Phanerozoic basement separating the West African and Congo cratons (After Ferre et al., 2002). 


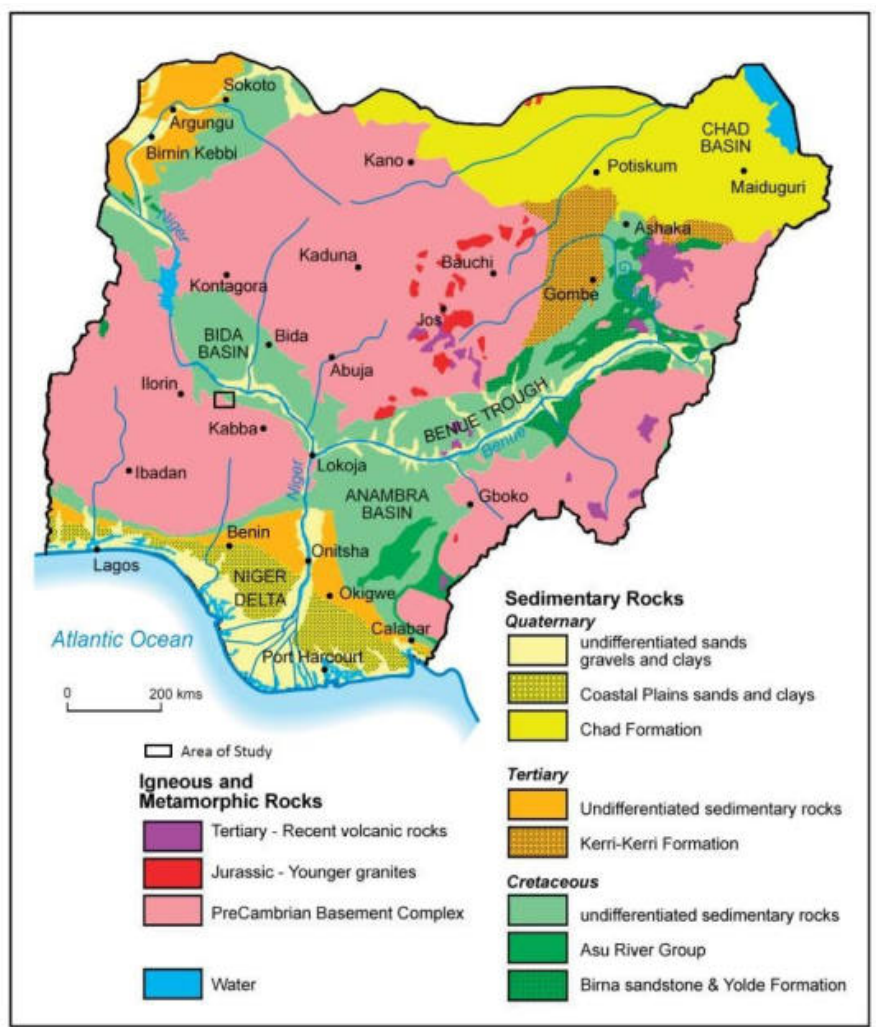

Figure 1b: Geological Map of Nigeria showing the area of study

\subsection{Geology of Study Area}

The study area is made up of the Pre-Cambrian Basement Complex rocks and partly the Cretaceous to Recent sediments of the Bida Basin (figure 2) The Cretaceous to Recent sediments of the Bida Basin occupy the northern half of the studied area and are composed of Recent alluvium which cover banks of tributaries and flood plains of the Niger River and sedimentary rocks of Nupe Sandstone. The Basement Complex rock units occupy the southern half of the area composing of granites, gneisses and metamorphic rocks into which are in folded Upper Proterozoic supra-crustal low grade metasedimentary and metavolcanic rocks. These are rocks of the migmatite gneiss complex, schists and paraschists which are depicted mainly by pelitic to semi pelitic quartz schists and quartzmica schists, amphibolites, biotite and granite gneisses, granites, and pegmatites. A detailed description of the geochemistry and petrogenetic evolution of these rocks can be found in Ajadi (2017). However, most of the pegmatites of Gbugbu, Lema and Bishewa areas are mainly the zoned types which have been extensively studied elsewhere by Okunlola and Ocan (2009) to be endowed in rare-metals, intruding mainly the pelitic to semi pelitic schists and gneisses with their dips cutting across the regional foliation trends of the host schists and gneisses. 


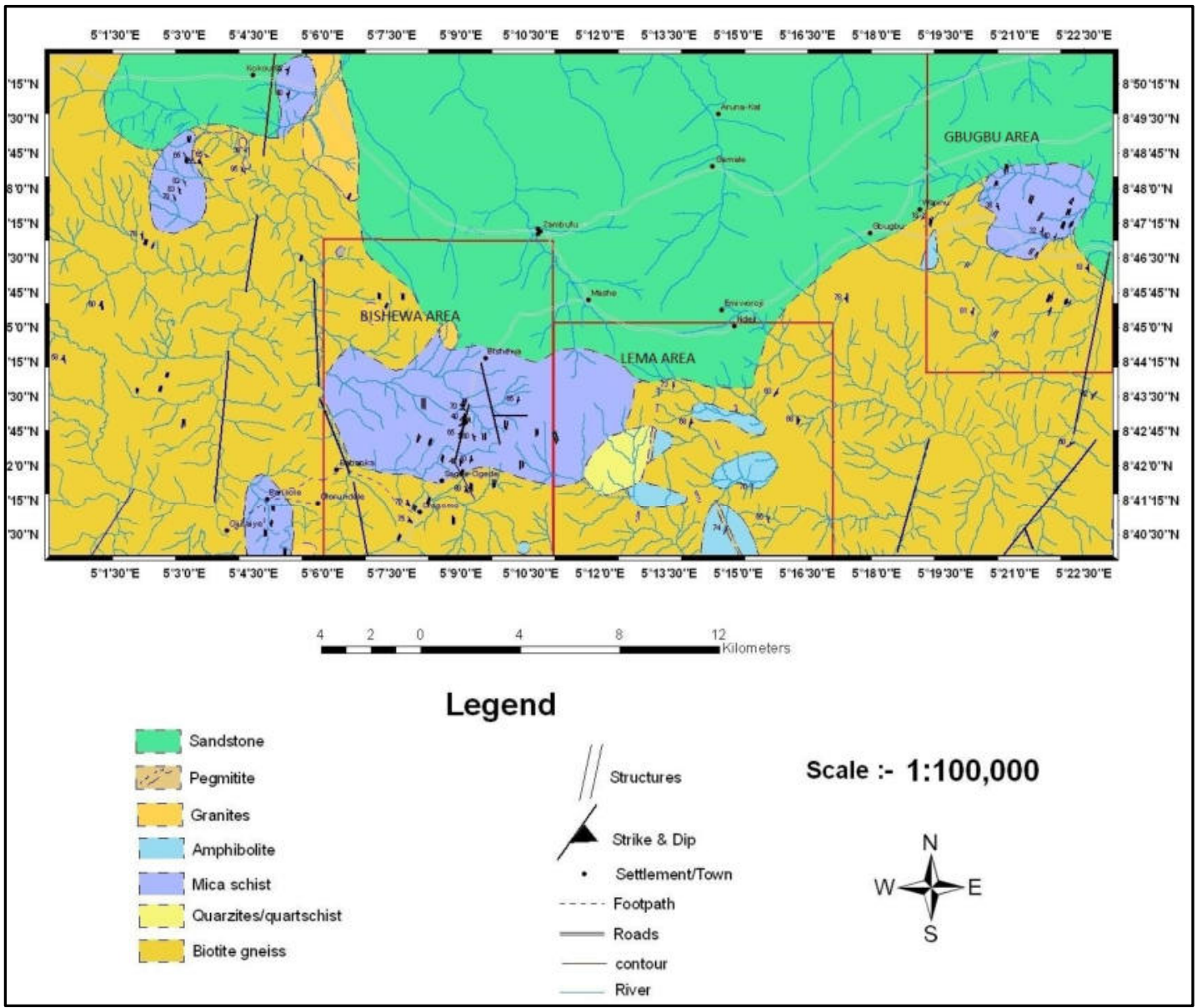

Figure 2: Geological Map of part of Lafiagi sheet. (Delineated are identified pegmatite bearing quadrants)

\subsection{Structural Patterns}

A multispectral Landsat TM satellite images was used to identify and produce a regional structural map showing lineaments (figure 3). Major structurally controlled features identified in the area are Rivers, Oyi and Oro which both have a trend in the NE - SW direction. The general foliation directions of the Basement Complex rocks are in the NNW/NNE and NNE/NNW directions respectively with a minor N-S trend. The rose plot of the strike direction of the pegmatites mirrors the general foliation trends determined for the gneisses and the schists with the major axes being NNW and NNE and minor axes of between NNW/N-S and NNE (figure 4). These orientations are consistent with the conjugate strike slip fault system in the NE-SW, and NW-SE which characterize the brittle deformation that took place at the closing stages of the Pan African orogeny according to Black (1980), Ball (1980) and Ajibade and Wright (1989). 


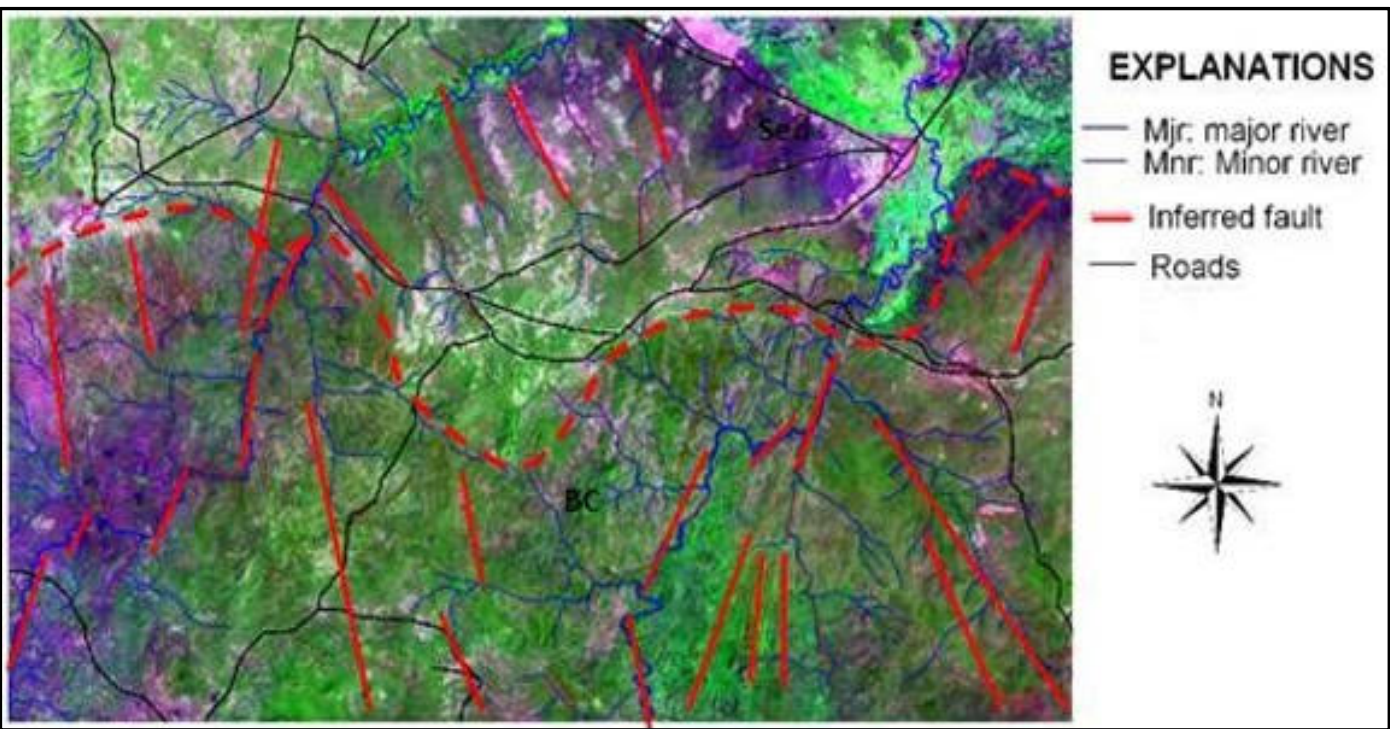

Figure 3: Landsat satellite image (1:50,000) and structural interpretation of project area showing dextral fault system. $\mathrm{BC}=$ Basement complex rocks. Sed=Sedimentary rocks

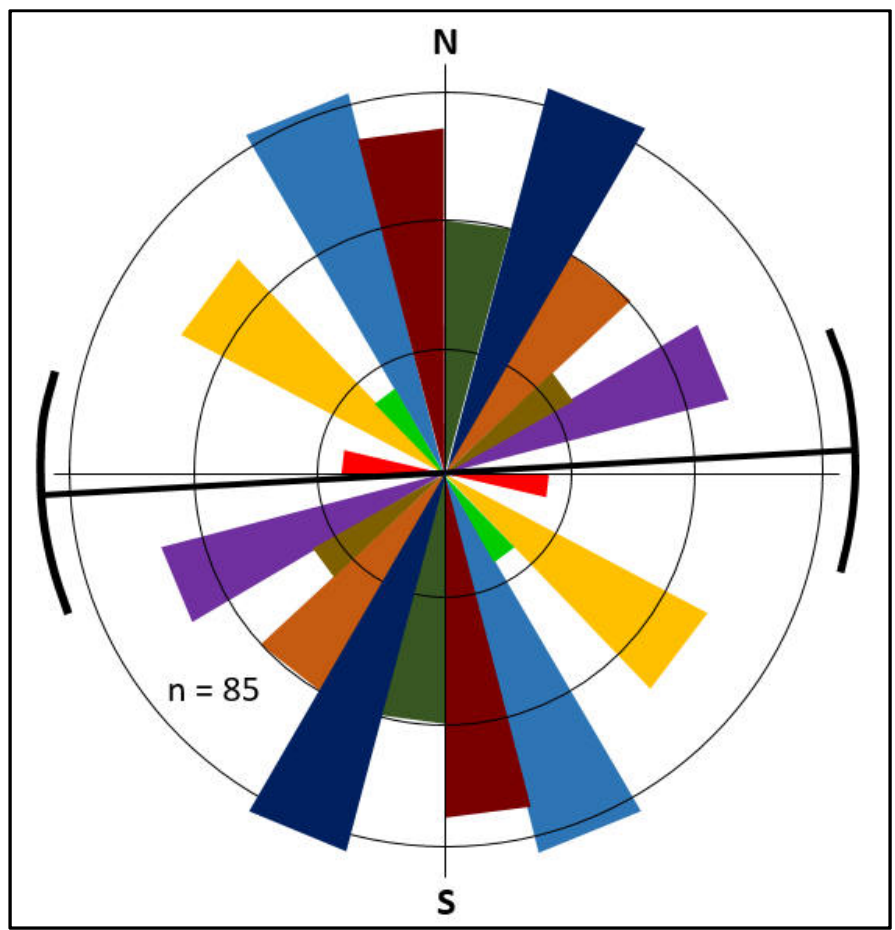

Figure 4: Rose plot of strike direction of pegmatite bodies in the study area

\subsection{Gbugbu Area Pegmatite Field}

The Gbugbu Forest pegmatites occur mainly as low lying intrusions into mainly biotite schists, quartz muscovite schists, massive amphibolites and gneisses. Their lateral extent rarely exceeds between $100 \mathrm{~m}-150 \mathrm{~m}$ with a width varying from $<0.5 \mathrm{~m}-5 \mathrm{~m}$. They are mostly complex types, K-feldspar rich pegmatites associated with occasional impregnation of cassiterite. Occasionally greisen bearing cassiterite mineralization are also associated with the pegmatites found in Gbugbu Forest Reserve. There are evidences of pnuematolysis which is manifested by pervasive tourmalinization of host gneisses proximal to some pegmatite bodies leading to the presence of tourmaline in almost all the zones of the pegmatite in Forest Reserve (Eika Camp). There is also an apparent alignment of the tourmalines in the host gneisses and schists, while those in the pegmatite bodies have their 
orientation perpendicular to the internal zoning of the pegmatite body, those in the contact zone within the gneisses are scattered. The morphology of the pegmatites are mostly linear and tabular bodies with well-defined internal zoning (figure 5).

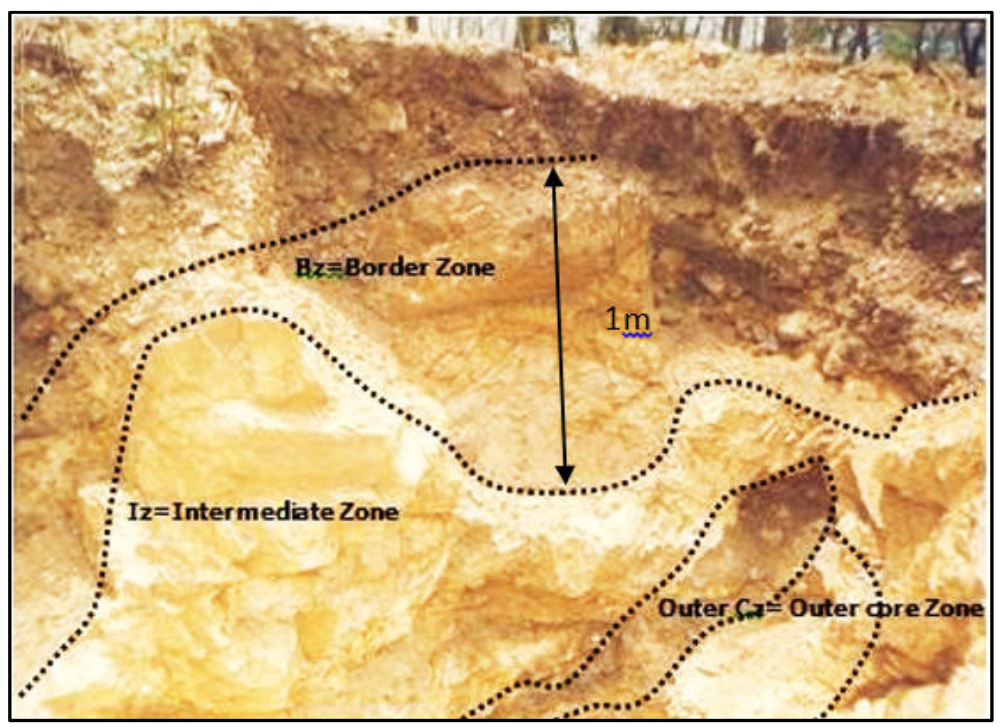

Figure 5: A typical pegmatite exposure in (Eika camp) Gbugbu pegmatite field showing the border zone $\mathrm{Bz}=\mathrm{K}$ feldspar $+\mathrm{Qtz}+$ Muscovite $\pm \mathrm{Sn} \pm$ Tourmaline, $\mathrm{Iz}=\mathrm{K}$-feldspar $\pm \mathrm{Sn} \pm$ tourmaline, Outer $\mathrm{Cz}=$ Muscovite $+\mathrm{K}-$ feldspar $+\mathrm{Sn} \pm$ tourmaline

\subsection{Lema Area Pegmatite Field}

The pegmatites of Lema pegmatite field forms a prominent topographic feature (Patikiesin hill) and intrudes amphibolite, schists and gneisses as shown in the geological map of Lema area. This pegmatite field is extensively kaolinized in parts and being worked on. Occasionally, the thickness of the kaolinized layer could reach $>4 \mathrm{~m}$. Field observation suggests the pegmatites are complex types with well-developed zoning. The intermediate zone is composed of K-feldspars and occasional mineralization of tantalite and wolframite were observed. Microlite \pm tantalite \pm beryl \pm tourmaline is the more noticeable mineralization in the altered outer core zone with the mineralogy containing quartz + muscovite + lepidolite + plagioclase (albite). The core zone of a pegmatite body (KW12A) was observed with the mineralogy containing mainly quartz + tourmaline \pm rubellite. It has an approximate strike direction of $60^{\circ}$. Detailed observation and mapping of the internal zonings of the pegmatites could not be made due to deep weathering (figure 6). Lithian mica is prominent here and is mostly found as relics in the weathered profile and also associated with the kaolinised layer. Mineralization is sometimes found associated with weathered kaolinized materials rich in lepidolites which are occasionally preserved due to their high resistance to weathering. 


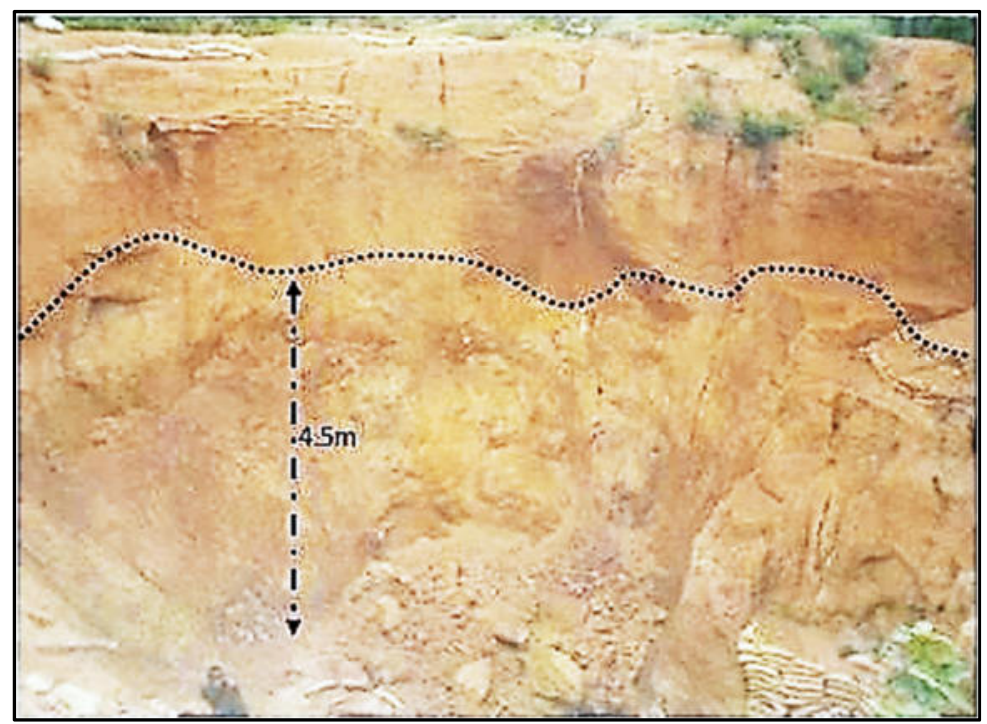

Figure 6: A weathered pegmatite exposure in the Lema pegmatite field showing intensive weathering and kaolinization of the feldspar rich zones of the pegmatite

\subsection{Bishewa Area Pegmatite Field}

The pegmatites of Bishewa field are variable in types having both simple and complex types with occasional occurrences of biotite and beryl. The simple types of pegmatites are found within biotite gneisses of Ologomo area southwest of Bishewa. The complex types of pegmatites in this field are mostly associated with schists and occasionally within the biotite gneisses. The pegmatites in this field are mineralized in rare metals and gemstones hosting mostly tantalite and beryl. The morphology of pegmatites in Ologomo and Bishewa also varies exhibiting the linear, layered and the bulbous types (figure 7). Their dimensions also vary with their lengths $>150 \mathrm{~m}$ and their width occasionally reaching $>5 \mathrm{~m}$. The structural orientation of the pegmatite bodies vary between $40^{\circ}$ and $50^{\circ}$.

\subsection{Petrography of Pegmatites}

Petrographic studies of some of the pegmatite rocks mainly from Gbugbu and Bishewa show the presence of quartz, feldspars, mica and other accessory minerals such as beryl, garnet and sphene. Some opaque ore minerals observed to be cassiterite and heamatite were noted in some thin section slides (figure 8). Microcline feldspar was observed in the filed as large euhedral crystals and sometimes as fine grained groundmass in association with quartz with which it frequently occurs. Extinction angles of the feldspars show most of them to average between $14-18$ and this corresponds to albite-oligoclase composition on the Michel Levy's chart. Macroscopic graphic and perthitic intergrowth of microcline feldspar with quartz is common in the pegmatites around Bishewa and Ologomo. Secondary alteration effects of sodium-metasomatism of microcline (albitization) were observed in the feldspars of some pegmatites located southwest of Ologomo. 


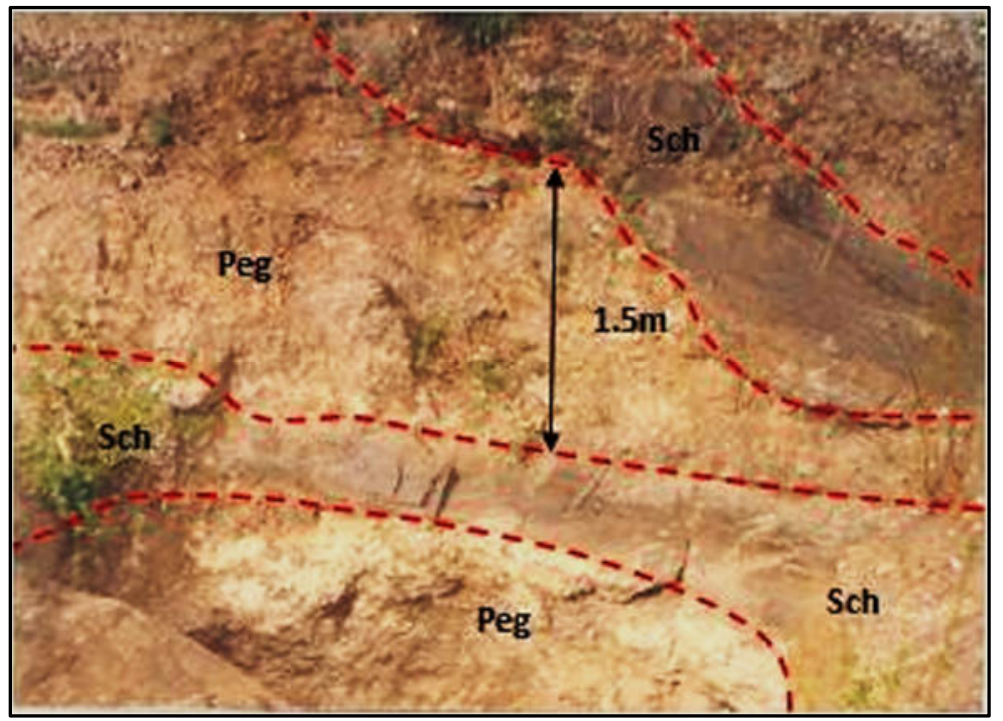

Figure 7: Interlayered pegmatite within the schist host rock near Bishewa along Bishewa-Ologomo road (Peg=layered pegmatite, $\mathrm{Sch}=$ schistose host rock)

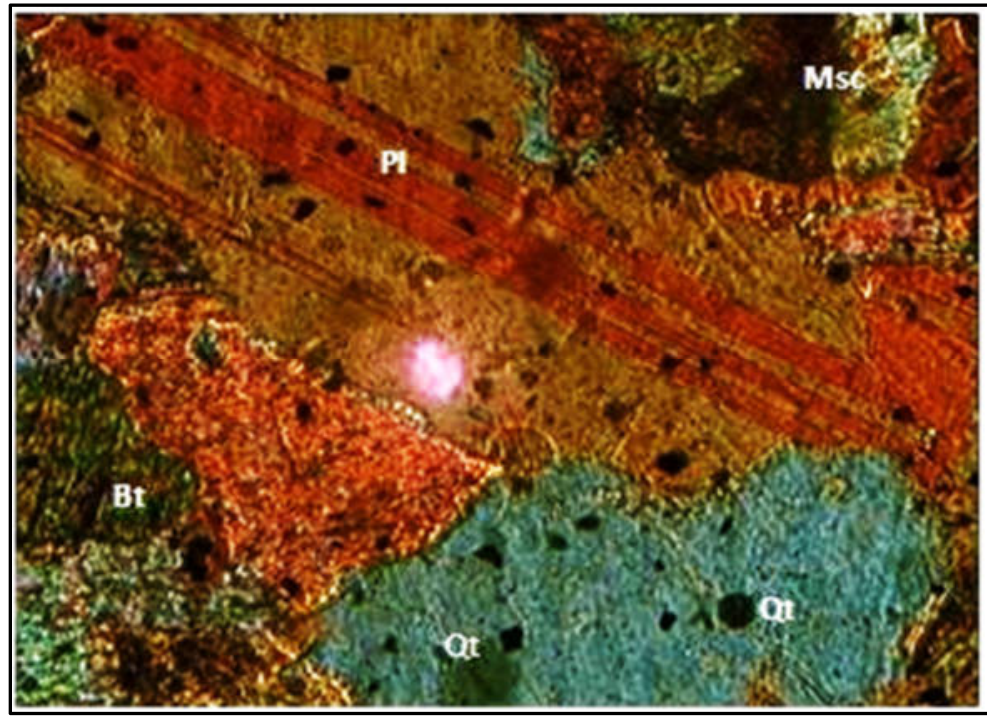

Figure 8: Photomicrograph of the layered pegmatite around Bishewa area $(\mathrm{Pl}=$ plagioclase, $\mathrm{Bt}=$ biotite, $\mathrm{Msc}=$ muscovite, $\mathrm{Qt}=$ quartz)

\section{Geochemical Results and Interpretation} 4.1 Major Elements

The concentrations of major elements composition in samples from the three pegmatite field are presented in table 1. The $\mathrm{SiO}_{2}$ concentrations in the Gbugbu field are relatively high and lie between $66.12 \%-76.85 \%$ with an average of $71.4 \%$ while $\mathrm{Al}_{2} \mathrm{O}_{3}$ ranges between $14.36-21.18 \%$ with an average of $16.94 \%$. Average $\mathrm{K}_{2} \mathrm{O}$ and $\mathrm{Na}_{2} \mathrm{O}$ content is $2.93 \%$ and $2.58 \%$ respectively while $\mathrm{CaO}$ content is $0.38 \% . \mathrm{Fe}_{2} \mathrm{O}_{3}$ content is moderately high with an average value of $2.04 \%$. The Aluminium Saturation Index (ASI) of the pegmatites in this field range between 1.62 and 6.58 with an average of 3.08 .

In the Lema Pegmatite field, major element concentration patterns indicated a relatively low $\mathrm{SiO}_{2}$ and high $\mathrm{Al}_{2} \mathrm{O}_{3}$ concentrations averaging $59.33 \%$ and $25.82 \%$ respectively. Alkali content is enhanced and averages of $3.57 \%$ and $5.08 \%$ for $\mathrm{Na}_{2} \mathrm{O}$ and $\mathrm{K}_{2} \mathrm{O}$ respectively while $\mathrm{CaO}$ content of $0.25 \%$ is low. The ASI values range between 
1.95 and 3.86 with an average of 2.92. The $\mathrm{Fe}_{2} \mathrm{O}_{3}$ content is generally low with an average value of $1.55 \%$ and the concentration of $\mathrm{TiO}_{2}$ is also low while $\mathrm{MnO}, \mathrm{MgO}$ and $\mathrm{P}_{2} \mathrm{O}_{5}$ are also comparatively low.

The major element distribution pattern in the Bishewa pegmatite field shows average concentration of $\mathrm{SiO}_{2}$ and $\mathrm{Al}_{2} \mathrm{O}_{3} 70.45 \%$ and $16.94 \%$ respectively. The concentration of alkalis $\left(\mathrm{Na}_{2} \mathrm{O}\right.$ and $\left.\mathrm{K}_{2} \mathrm{O}\right)$ averages $(3.59 \%)$ and $(3.20 \%)$ respectively. The concentrations of $\mathrm{Fe}_{2} \mathrm{O}_{3}, \mathrm{TiO}_{2}, \mathrm{P}_{2} \mathrm{O}_{5}$ and $\mathrm{MgO}$ are comparatively low. The Aluminum Saturation Index (ASI) of the samples range between 1.64 and 3.04 with an average of 2.2.

\subsection{Trace Elements}

Trace element pattern and distribution in the muscovite sampled from the pegmatites in the three fields and elemental ratios of some selected trace elements are presented in tables 2a-e. This show enrichment in the rare metal concentrations ( $\mathrm{Rb}, \mathrm{Cs}, \mathrm{Nb}, \mathrm{Ta}$ and $\mathrm{Sn}$ ) with the following range of averages in the three pegmatite fields respectively 470.78ppm-1464ppm, 35.91295.6ppm, 54.11-166.3ppm, 63.6-229.6ppm and Sn 31.6-127.3ppm. The high $\mathrm{Rb} / \mathrm{Sr}$ and low $\mathrm{K} / \mathrm{Rb}$ and $\mathrm{K} / \mathrm{Cs}$ suggest the pegmatites are granitic in origin. The ratio of $\mathrm{Nb} / \mathrm{Ta}(1.33)$ is relatively enhanced in the Bishewa pegmatite field while average $\mathrm{Ta} / \mathrm{Nb}$ value is enhanced in the Lema pegmatite field. Also the ratio of Ta/W is comparative higher in Lema pegmatite field compared to the Gbugbu and Bishewa pegmatite field. The plots of elemental ratios of $\mathrm{K} / \mathrm{Rb}$ vs $\mathrm{Cs}, \mathrm{K} / \mathrm{Cs}$ vs $\mathrm{Rb}$ and $\mathrm{Ta} / \mathrm{W}$ vs $\mathrm{Cs}$ are used to discriminate the rare metal bearing potentials of the individual pegmatite bodies sampled. The plots of $\mathrm{K} / \mathrm{Rb}$ vs Cs of Cerny and Burt (1984) and the K/Rb vs Cs plot of Gallinski et al (1997). Figures 9 and 10 indicate that the majority of the samples plot within the rare element class of pegmatites except five samples from Bishewa and Gbugbu field.

Figure 10 shows that the majority of the pegmatite bodies belong to type II-IV [Be, Li-Be-(Ta), and Li-Cs-Be(Ta) pegmatites with only four samples from Bishewa and Gbugbu plotting within the Barren or muscovite type field. Majority of the pegmatites from the Lema field also plots within the type III and type IV [Li-Be-(Ta), and Li-Cs-Be (Ta)] pegmatites respectively while few others belong to the Be-type II pegmatites. The K/Cs vs Rb plot of Gallinski et al (1997) and $\mathrm{K} / \mathrm{Rb}$ vs $\mathrm{Rb} / \mathrm{Sr}$ plot of Oyarzabal and Cadile 2004 (figures 11 and 12) also show the rare-metal bearing potentials and geochemical characteristics of each of these pegmatite fields. Comparison of $\mathrm{K} / \mathrm{Rb}$ vs $\mathrm{Cs}, \mathrm{K} / \mathrm{Cs}$ vs $\mathrm{Rb}$ plots of Gallinski et al (1997) and the $\mathrm{Ta} / \mathrm{W}$ vs Cs plots (figures 11, 12 and 13) suggest that the pegmatites of Lema field are highly evolved, belonging to the type IV [Li-Be-Cs-(Ta) bearing] pegmatites.

The Ta/W vs Cs plot also shows that the Lema-Gbugbu-Bishewa pegmatites are comparable with mineralized pegmatites locally and some world class rare-metal bearing pegmatites. The Lema pegmatites show similarity with the Buck, Oasis and Tanco pegmatites of Canada (Morgan and London, 1987), while the Gbugbu and Bishewa pegmatites plot in the fields of Noumas, Homestead and Wodgina pegmatites of Western Australia. Similarly on the local scene, the Lema pegmatites plot in the field of Nassarawa-Keffi pegmatites (Akintola, 2003) and, Oke-Ogun and Kushaka pegmatites (Garba, 2002) fields while the Gbugbu and Bishewa pegmatites have close affinity with the Kabba-Isanlu pegmatites (Annor and Freeth, 1985; Annor et al, 1995), Aramoko- Ijero and Osogbo-Ibadan pegmatites (Okunlola, 2005) fields. The Rb vs Sr plot of Condie (1976) (figure 14) suggests that the pegmatites were emplaced over a depth range of between $20-30 \mathrm{Km}$. 


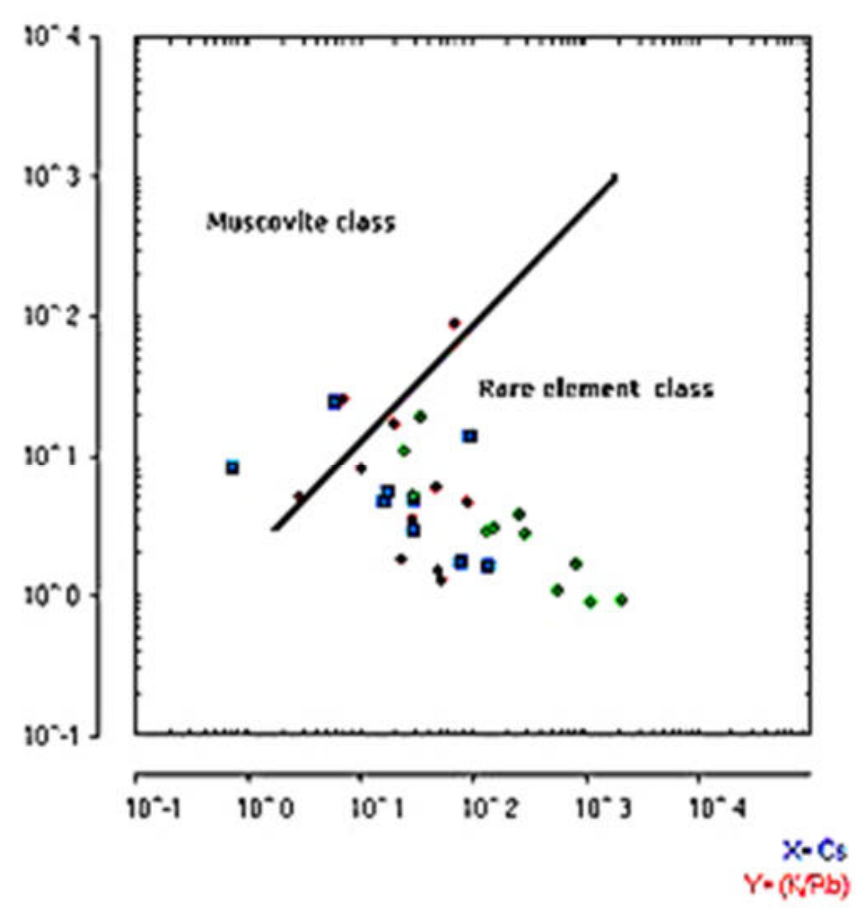

- Lema Pegmatite field samples

a vishena Pegmatite fleld samples

- Gbugbu Pegmatite fleld somples

Figure 9: $\mathrm{K} / \mathrm{Rb}$ vs Cs classifying the pegmatites into Muscovite class and rare element class (After Cerny and Burt, 1984).

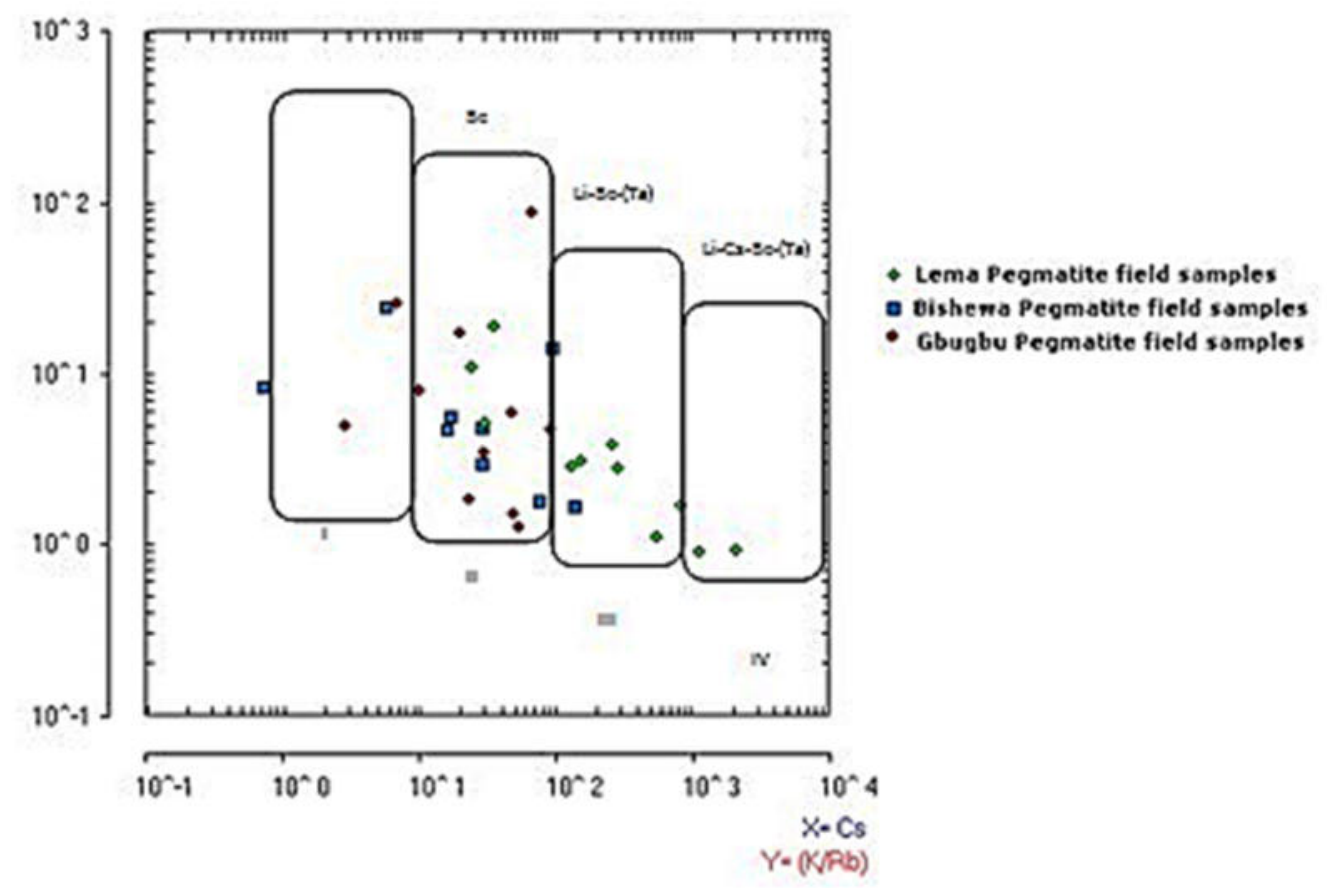

Figure 10: $\mathrm{K} / \mathrm{Rb}$ vs Cs plot classifying the range of types of pegmatites within the pegmatite fields. The polygons describe the types. I-Muscovite class, II-Be, III-Li-Be-(Ta), IV- Li-Cs-Be-Ta pegmatites (After Gallinski.et al, 1997) 


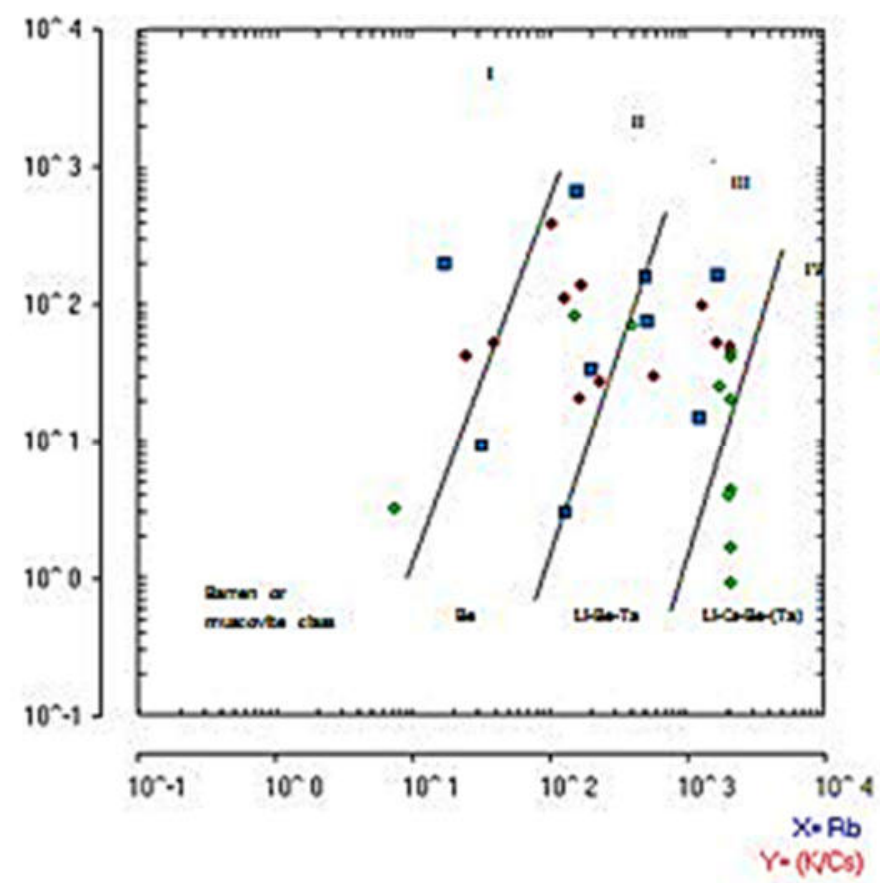

Figure 11: K/Cs vs Rb plot classifying the range of types of pegmatites within the pegmatite fields. The lines discriminate between the various types. I-Muscovite class, II-Be, III -Li-Be-(Ta), IV- Li-Cs-Be-Ta. (After Gallinski.et al, 1997).

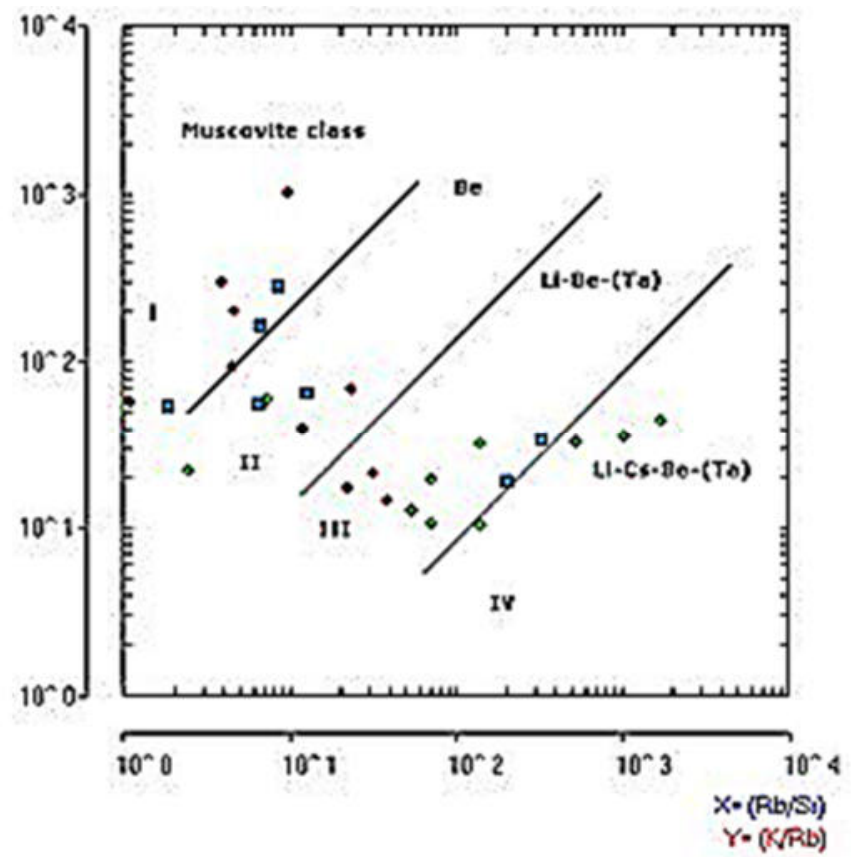

- Lema Pegmatite fleld somples a Oishena Pegmatite fleld somples - Gbugbu Pegmatite fleld somples

Figure $12: \mathrm{K} / \mathrm{Rb}$ vs $\mathrm{Rb} / \mathrm{Sr}$ classifying the range of types of pegmatites within the pegmatite fields. The lines discriminate between the various types. I-Muscovite class, II-Be, III-Li-Be-(Ta),IV- Li-Cs-Be-Ta. (After Oyarzabal and Cadile, 2004). 

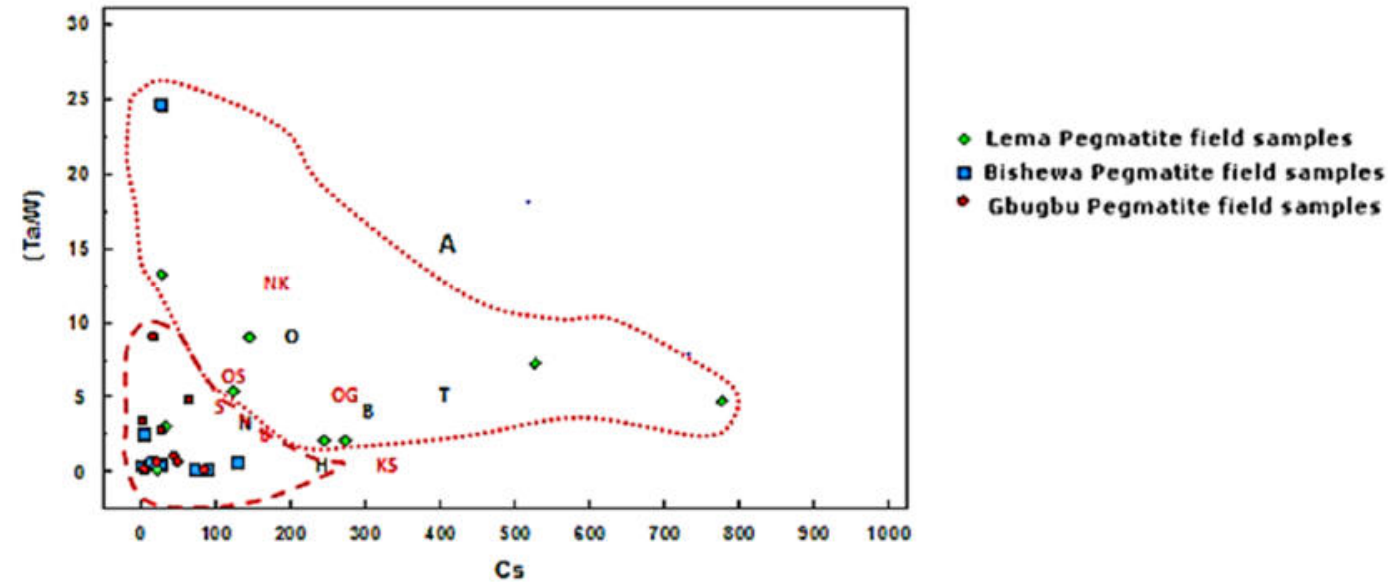

Figure 13: Ta/W vs Cs plot comparing the Gbugbu-Lema-Bisewa pegmatites with other local pegmatite bodies and world class pegmatite deposits. NK- Nassarawa-Keffi, Ks-Kushaka, OG- Oke-Ogun, OS-Awo, IJ-Ijero, SIsanlu (Red print). T- Tanco, O.Oasis, N.Nuemas, H- Homestead/Wodgina.

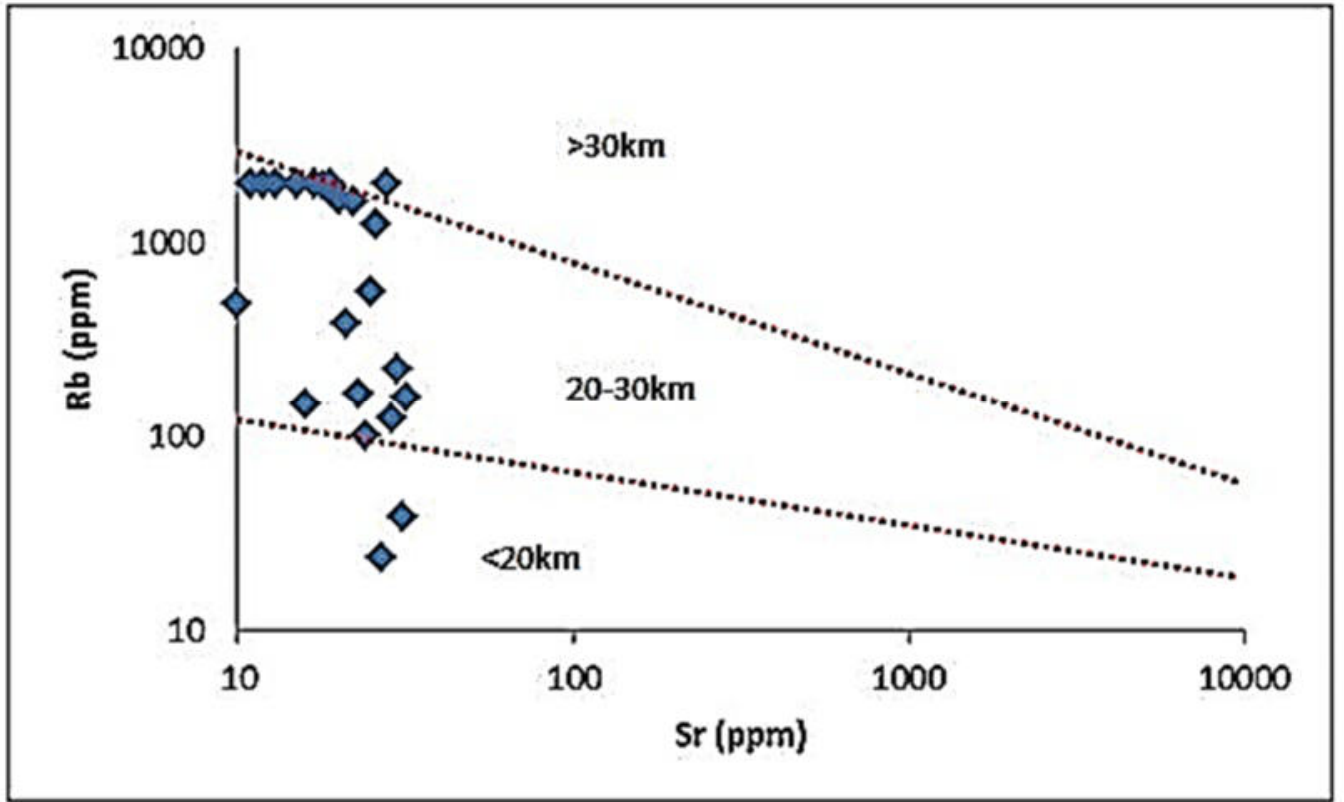

Figure 14: Rb vs Sr depth classification plot of Condie (1976) showing majority of the pegmatites plotting within a depth range of $20-30 \mathrm{~km}$.

4.3 Geochronology and K-Ar Age Dating Result

The analytical results for each pegmatite sample were used to calculate the age for the respective samples using the general model age equation below (Faure, 1986; Dickin, 1995).

$$
t=\frac{1}{\lambda} \ln \left(\frac{D t+D o}{P t}+1\right)
$$

Where:

$t \quad=$ age of pegmatite 
$\lambda=$ decay constant of the parent isotope, ${ }^{40} \mathrm{~K}=5.543 \times 10^{-10}$

$D t=$ present number of radiogenic daughter atoms in the rock

$D o=$ initial number of daughter atoms in the rock

$P t=$ present number of parent atoms in the rock

By assuming that the radiogenic argon was zero in the pegmatite when it was formed, $D t$ and $P t$ were measured, and the age equation above was then used to determine ages of the rocks. The K/Ar geochronological ages so obtained from this study indicates a range between 512, 516 and 520Ma for the muscovite extracts from pegmatites of Lema, Bishewa and Gbugbu fields respectively. These ages which suggests muscovite blocking ages in the pegmatite bodies are comparable to the 529 - 539Ma Rb-Sr mineral ages obtained on muscovite and lepidolite of Osi area (Jacobson et al 1963); 487 - 490Ma K-Ar ages of muscovite of Aramoko and Ijero area (Matheis and Caen-Vachette 1983) and the reported 590Ma - 538Ma K-Ar ages on microcline, muscovite and orthoclase from pegmatites of Jos Plateau (Tugarinov et al 1968). In addition to these, the ages are comparable to the K-Ar ages on muscovite of 521, 545, and 656Ma obtained in Zaria north western Nigeria by Harper et al. (1973) and the ${ }^{40} \mathrm{Ar} /{ }^{39} \mathrm{Ar}$ spectrum ages of 506 - 514Ma obtained on micas of Egbe pegmatites as reported by Akande and Reynolds (1990).

\section{Discussions and Conclusion}

\subsection{Discussions}

The Gbugbu-Lema-Bishewa pegmatites which were emplaced in granites, gneisses and schist of variable composition exhibit structural trends mainly in the NE-SW, N-S and NW-SE directions and with a minor E-W direction (Garba 2011). These trends may have resulted from reactivation of ancient lineaments at the waning stage of the Pan African orogeny which according to Wright (1976), Ajibade and Wright (1989) and Okunlola (2005), controls pegmatite and tin mineralization. The K-Ar mineral age range of between $512-520 \mathrm{Ma}$ determined for the three pegmatite fields are close to those obtained by earlier workers for pegmatites of Lokoja, Ijero, Egbe and Komu areas but younger than those obtained for Zaria and Jos in the northern parts of Nigeria. This suggests the cooling ages of pegmatites in Nigeria span a period of time or perhaps the pegmatites were emplaced in phases.

Cerny (1986, 1990a, 1991a, 1992a \& b, 1994) and Cerny and Meintzer (1988) have worked extensively on the evolution, geochemistry and petrogenetic features of pegmatites which have been used to characterize the Gbugbu-Lema-Bishewa pegmatites. The pegmatites in the three fields show a general decrease in the alumina saturation index with increase in $\mathrm{Na}_{2} \mathrm{O}$ from Gbugbu field in the northeast down to Bishewa field in the southwest. The relative enhancement in $\mathrm{Na}_{2} \mathrm{O}$ with moderate $\mathrm{Na} / \mathrm{K}$ may be as a result of secondary enrichment due albitization which is moderate in all the three pegmatite fields. This elevated sodic content is typical of highly evolved granitic pegmatites according to Cerny (2005). The geochemical trends of the lithophile such as Cs and $\mathrm{Rb}$ indicate the pegmatites of Lema field are comparatively highly fractionated. The ratios of $\mathrm{K} / \mathrm{Cs}$ and $\mathrm{K} / \mathrm{Rb}$ in micas have generally been used as indices of fractionation in granites and pegmatites Cerny (1991b), plots K/Cs vs $\mathrm{Rb}$ and $\mathrm{K} / \mathrm{Rb}$ vs $\mathrm{Cs}$ depicts a compositional gradient in pegmatites with the Lema pegmatite field exhibiting higher degree of fractionation. Furthermore discrete mineralization of ore grade microlite woframite and tantalite which were being mined was observed in Lema and Bishewa pegmatite fields. Conversely, in Gbugbu pegmatite field niobium, tin and gemstones (tourmaline) are the major minerals being mined with subsidiary amount of tantalite.

\subsection{Conclusion}

The Gbugbu-Lema-Bishewa pegmatite which were emplaced at the waning stages of the Pan African Orogeny (512-520Ma) are the peraluminous type of pegmatites with the degree of albitization $(\mathrm{Na} / \mathrm{K})$ values $>1$ across the three pegmatite fields. There is compositional variability across the three identified pegmatite fields which indicated by enrichment in rare alkalis ( $\mathrm{Li}, \mathrm{Rb}$ and $\mathrm{Cs}$ ). This suggests comparatively higher enrichment in raremetals in the pegmatites of Lema pattern which suggests variability in their enrichment patterns and regional zonation. This enrichment in rare alkalis of $\mathrm{Li}, \mathrm{Cs}, \mathrm{Rb}$ is expectedly followed by corresponding enhancements in rare-metal mineralization. The variation plots of $\mathrm{K} / \mathrm{Rb}$ vs $\mathrm{Cs}, \mathrm{K} / \mathrm{Cs} \mathrm{vs} \mathrm{Rb}$ and $\mathrm{K} / \mathrm{Rb} \mathrm{vs} \mathrm{Rb} / \mathrm{Sr}$ shows consistency of the pegmatite samples from each of these locations with the Lema pegmatite field being more evolved and belonging mainly to the Li-Be Ta (Type III) and Li-Cs-Be Ta (Type IV) class of rare-metal bearing pegmatites while the Gbugbu and the Bishewa pegmatite fields appear to be less endowed comparatively and transcend the muscovite class (Type I) and Li-Be Ta (Type III). 


\section{References}

Ajadi, J. (2017) Geochemistry and Petrogenetic Evolution of Rocks around Bishewa-Ologomo area, part of Lafiagi Sheet 203, Northcentral Nigeria. In Int. Jour. of Sci. Engr. Res. Vol. 8 (4), p 1333-1343.

Ajibade, A. C. and Wright J. B. (1989) The Togo-Benin Nigerian Shield evidence of crustal aggregation in the Pan African belt. Tectonophysics 165. p 125-129.

Akande, S. O. and Reynolds, P. H. (1990) 40Ar/39Ar Spectrum Ages of Micas from The Sn-Nb-Ta bearing Pegmatites in Nigeria. In Proceedings vol. 15th Colloquim of African Geology. Centre International Pour la Formation Ets Les Echanges Geologiques (CIFEG) Occasional Publication 1990. Vol.20. 243p.

Akintola, O. F. (2003) Petrogenesis and ore bearing potentials of pegmatites in the Nassarawa area of Central Nigeria. Unpubl. Ph.D thesis. Univ of Ilorin. Nigeria. 163p.

Annor, A. E., Olobaniyi, S. B. and Mucke, A. (1995) A note on the geology of the Isanlu area, in the Egbe- Isanlu schist belt, S.W. Nigeria Journal of Mining and Geology. Vol 32(1) p 47-52.

Annor, A. E and Freeth, S. J. (1985) Thermotectonic evolution of the basement Complex around Okene, Nigeria with special reference to deformation mechanism: Precambrian. Research. Vol. 28. p 73-77.

Ball, E. (1980) An example of very consistent brittle deformation over a wide intracontinental area: The late Pan African fracture system of the Tuareg and Nigerian shield. Tectonophysics. Vol. 61, p 363-379.

Black, R. (1980) Precambrian of West Africa Episodes. Vol. 4, p 3-8.

Cerny, P. (1986) Characteristics of pegmatites deposits of tantalum. Proceedings of Berlin workshop of Lanthanides, Tantalum and Niobium P. Moller, P. Cerny and F. Saupe (Eds) Society of Mineral Explorationists. 65p.

Cerny, P. (1990a) Rare-element granitic pegmatites. Part I: Anatomy and internal evolution of pegmatite deposits.Geosci.Canada, Vol.18. p 49-67.

Cerny, P. (1991a) Fertile granites of Precambrian rare-element pegmatite fields: is geochemistry controlled by tectonic setting or source lithologies? Precambrian Research. Vol.51. p 429-468.

Cerny, P. (1991b) Rare-element granite pegmatites. Part II: Regional to Global environments and petrogenesis. Geosci. Canada, Vol.18. p 68-81.

Cerny, P. (1992a) Geochemical and petrogenetic features of mineralization in rare-element granitic pegmatites in the light of current research. Applied Geochem. Vol. 7. p 393-416.

Cerny, P. (1992b) Regional zoning of pegmatite populations and its interpretation. Mitt. Oster. Miner. Ges. No.137. p 99-107.

Cerny, P. (1994) Evolution of feldspars in granitic pegmatites. In: I. Parson (ed). Feldspars and their reactions. Kluwer Academic Publishers. Netherland. p 501-540.

Cerny, P. (2005) The Tanco rare-element pegmatite deposit Manitoba: Regional context, internal anatomy and global comparisons: In: R.L. Linen and I.M. Samson (eds): Rare-element geochemistry and mineral deposits. Geol. Assoc. Canada short course notes. Vol 17. p 127-158.

Cerny, P. and Burt, D. M. (1984) Paragenesis and crystallo-chemical characteristics and geochemical evolution of micas in granite pegmatites: In: S.W. Bailey (ed). Mineral. Soc. America, Rev. in Mineralogy. Vol.13. p 257297.

Cerny, P. and Meintzer, R. E. (1988) Fertile granites in Archean and Proterozoic fields of rare-elements pegmatites: Crustal environment, geochemistry, and petrogenetic relationships. In: R. P. Taylor and D. F. Strong. (eds). Recent advances in the geology of granite-related mineral deposits. Canadian Institute of Mining Metallurgy Special Publication Vol. 39 p170-377.

Condie, K. D. (1976) Trace element geochemistry of Archean granite from Barberton Region. South Africa. Earth Planet. Sc. Letter, p 300-400.

Dada, S. S. and Briqueu, L., (1998) $\mathrm{Pb}-\mathrm{Pb}$ and Sm-Nd Isotopic study of meta-igneous rocks of Kaduna: implications for the Archean mantle in Northern Nigeria, 32nd Annual. Conf. Nigeria Min. Geosc. Soc; Benin City. Abstr. 57p.

Dickin, A. P. (1995) Radiogenic isotope geology. Cambridge: Cambridge University Press.

Faure, G. (1986) Principles of isotope geology (2nd ed.) New York: John Wiley and Sons.

Ferre', E., Gleizes, G., Caby, R., (2002) Obliquely convergent tectonics and granite emplacement in the TransSaharan belt of Eastern Nigeria: a synthesis. Precambrian Research 114, p 119-219.

Galliski, M. Perino, E. Gasquez, J. Marquez, Z. M. and Olsina, R. (1997) Geochemistry of K-feldspars and muscovite in exploration of granitic pegmatites in Pampeana province Argentina. Rev. Assoc. Geol. Argentina. Vol. 52. p 24-32.

Garba. A. A (2011) Geology, Geochemistry and Rare-metal Bearing Potentials of Gbugbu, Lema and Bishewa areas, North Central Nigeria. Unpub. Ph.D. Thesis Univ. of Ilorin. 224p.

Garba, I. (2002) Late Pan African tectonics and origin of gold mineralization and rare metal pegmatites in Kushaka schist belt, Northwestern Nigeria. Journal of Mining and Geology. Vol.38 (10), p 1-12.

Garba, I. (2003) Geochemical discrimination of newly discovered rare metal bearing and barren pegmatites in the 


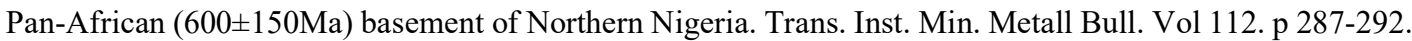

Grant, N. K. (1971) A compilation of radiometric ages from Nigeria. Journal of Mining and Geology. Vol 6. p $37-$ 54.

Harper, C.T., Sherrer, G., McCurry, P. and Wright, J.B. (1973) K-Ar retention ages from the Pan-African of northern Nigeria. Geol. Soc. America Bull., 84, p. 919-926.

Jacobson, R. and Webb, J.S. (1946) The Pegmatites of Central Nigeria. Nig. Geol. Surv. Bull 17: 61p.

Jacobson, R. E. E., Snelling, N. J. and Truswell, J. F. (1963) Age determination in the geology of Nigeria, with special reference to the Older and Younger Granites. Overseas Geol. Miner. Resour. 9, p 168-182.

Kuster, D. (1990) Rare metal pegmatite of Wamba, central Nigeria; their formation in relationship to late PanAfrican granite. Mineral. Deposita. Vol. 25. p 25-33.

Matheis, G. (1991) Structural reactivation and rare metal accumulation: Case studies in Nigeria and Egypt. Zentralblatt fur Geologie and Palaontologie (eds) R.O Greiling and G. Matheis. Issue II. p. 2661-2673.

Matheis, G. (1987) Nigerian rare metal pegmatites and their lithological framework Journal of Mining and Geology. Vol. 22. p 271-291.

Matheis, G. and Caen-Vachette (1983). Rb-Sr isotopic study of rare metal bearing and barren pegmatites in the Pan-African reactivation zone of Nigeria. Journal of African Earth Science. Vol. 1. p 35-40.

McCurry, P. (1971) Pan African orogeny in Northern Nigeria: Geol. Soc. Amer. Bull. Vol. 82, p 3251-3263.

Moller, P. and Morteani, G. (1987a) Geochemical exploration guides for tantalum pegmatites. Econ. Geol. Vol 42. p 1888-1897.

Morgan, G. B. and London, D. (1987). Alteration of amphibolitic wall rock around Tanco rare-element pegmatite, Bernic Lake Manitoba. Amer. Mineral. Vol 72. p 1097-1121.

Odeyemi, I. (1988) Lithostratigraphy and structural relationships of the upper Precambrian metasediments in Igarra area, Southwestern Nigeria: In: Precambrian Geology of Nigeria. Nig. Geol. Surv. p 111-125.

Okunlola, O. A. and Ocan, O. O. (2009) Rare metal distribution in Precambrian pegmatites of Keffi area, Central Nigeria. Nature and Science. Vol. 7 (7). p 90-99.

Okunlola, O. A. (2005) Metallogeny of Tantalum - Niobium mineralization in Precambrian pegmatites of Nigeria. Mineral Wealth. Vol. 137 p 38-50.

Oyarzabal, J. and Cadile, S. (2004) Geology, geochemistry and petrogenesis of the Yastato-San Bernardo Libearing pegmatite Argentina. Appl. Miner. p 793-796.

Preinfalk, C, Morteani, G. and Huber, G. (2000) Geochemistry of granites and pegmatites of Minas Gerias, Brazil. Chemical Geology. Vol 60. p 305-326.

Rahaman, M. A. (1988) Recent advances in the study of Basement Complex of Nigeria. In: Precambrian Geol. Nigeria. Nig. Geol. Surv. Publication. p 11-43.

Rahaman, M. A. Emofurieta, W. D. and Caen-Vachette, M. (1983) The potassic granites of the Igbetti area: Further evidence of the polycyclic evolution of the Pan African belt in Southwestern Nigeria. Precambrian Research. Vol. 22. p 27-92.

Tugarinov, A. I., Knorre, K. G., Shanin, L. L. and Prokofieva, L. N. (1968) The geochronology of some Precambrian rocks of southern West Africa. Can. J. Earth Sci. 5, p 639-642.

Wright, J. B. (1976) Fracture systems in Nigeria and initiation of fracture zones in the south Atlantic: Tectonophysics, Vol. 34. p 43-47.

\section{Authors' Biographies}

The first author, Dr. Abdulrasaq A. GARBA, is currently the Director-General of the Nigerian Geological Survey Agency. He holds a B.Sc degree in geology, M.Sc and Ph.D degrees in geochemistry and mineral exploration.

The second author, Prof. Jacob I. D. Adekeye holds a B.Sc degree in geology, M.Sc and Ph.D degrees in mineral exploration and he is a professor of geochemistry, mineralogy and mining of the department of geology and mineral sciences, University of Ilorin, Nigeria.

The third author, Prof. Samuel O. Akande holds a B.Sc degree in geology, M.Sc and Ph.D degrees and he is a professor of geochemistry and economic geology of the department of geology and mineral sciences, University of Ilorin, Nigeria.

The fourth author, Dr. Jimoh Ajadi holds a B.Sc degree in geology, M.Sc and Ph.D degrees in mineral exploration, geochemistry, petrology and geochronology, and a lecturer at the department of geology and mineral sciences, Kwara State University, Malete, Nigeria. 
Table 1: Major element composition of Gbugbu, Lema and Bishewa pegmatites (\%)

\begin{tabular}{|c|c|c|c|c|c|c|c|c|c|c|c|c|c|c|c|c|}
\hline SAMPLES (Gbugbu) & $\mathrm{SiO}_{2}$ & $\mathrm{Al}_{2} \mathrm{O}_{3}$ & $\mathrm{Fe}_{2} \mathrm{O}_{3}$ & $\mathrm{MgO}$ & $\mathrm{CaO}$ & $\mathrm{Na}_{2} \mathrm{O}$ & $\mathrm{K}_{2} \mathrm{O}$ & $\mathrm{TiO}_{2}$ & P205 & $\mathrm{MnO}$ & LOI & TOT/C & TOT/S & SUM & $\mathrm{A} / \mathrm{C}+\mathrm{N}+\mathrm{K}$ & $\mathrm{Na} / \mathrm{K}(\mathrm{ppm})$ \\
\hline кWззв & 67.04 & 14.36 & 7.52 & 2.09 & 0.53 & 1.01 & 3.72 & 1.04 & 0.08 & 0.13 & 2.3 & 0.01 & 0.01 & 99.99 & 2.73 & 0.28 \\
\hline kW46C & 72.75 & 17.27 & 0.69 & 0.04 & 0.52 & 3.13 & 3.21 & 0.01 & 0.33 & 0.03 & 1.9 & 0.02 & 0.01 & 99.92 & 2.52 & 1.01 \\
\hline кW92B & 74.76 & 12.49 & 4.19 & 1.46 & 1.24 & 1.42 & 1.91 & 0.23 & 0.89 & 0.11 & 1 & 0.02 & 0.03 & 99.85 & 2.73 & 0.77 \\
\hline KW33A & 75.03 & 16.48 & 0.63 & 0.03 & 0.6 & 1.27 & 3.51 & 0.01 & 0.32 & 0.02 & 2.2 & 0.01 & 0.01 & 100.12 & 3.06 & 0.37 \\
\hline kW96 & 76.85 & 11.05 & 3.9 & 1.45 & 0.18 & 0.28 & 3.67 & 0.52 & 0.02 & 0.05 & 1.9 & 0.06 & 0.01 & 100.01 & 2.68 & 0.079 \\
\hline kW85 & 71.91 & 16.37 & 0.1 & 0.01 & 0.59 & 7.34 & 2.17 & 0.01 & 0.66 & 0.07 & 0.5 & 0.01 & 0.01 & 99.78 & 1.62 & 3.5 \\
\hline KW46A & 72.78 & 17.49 & 0.75 & 0.01 & 0.32 & 2.28 & 3.67 & 0.01 & 0.31 & 0.1 & 2.1 & 0.06 & 0.01 & 99.86 & 2.79 & 0.64 \\
\hline KW76 & 70.61 & 18.89 & 0.14 & 0.05 & 0.1 & 2.61 & 3.04 & 0.03 & 0.26 & 0.01 & 4.1 & 0.43 & 0.05 & 99.87 & 3.29 & 0.89 \\
\hline kW25 & 66.12 & 21.18 & 2.52 & 0.21 & 0.02 & 2.1 & 1.1 & 0.19 & 0.04 & 0.03 & 6.2 & 0.06 & 0.01 & 99.77 & 6.58 & 1.98 \\
\hline kw99 & 68.85 & 20.42 & 1.03 & 0.01 & 0.07 & 1.02 & 4.87 & 0.01 & 0.03 & 0.55 & 3 & 0.03 & 0.01 & 99.87 & 3.43 & 0.21 \\
\hline kw9o & 68.71 & 18.65 & 0.95 & 0.12 & 0.05 & 5.94 & 1.36 & 0.07 & 0.16 & 0.05 & 3.8 & 0.05 & 0.01 & 99.88 & 2.54 & 4.53 \\
\hline Average & 71.4 & 16.78 & 2.04 & 0.49 & 0.38 & 2.58 & 2.93 & 0.19 & 0.28 & 0.1 & 2.64 & 0.07 & 0.02 & 99.9 & 3.08 & 1.29 \\
\hline SAMPLES (Lema) & $\mathrm{SiO2}$ & Al2O3 & $\mathrm{Fe} 203$ & $\mathrm{MgO}$ & $\mathrm{CaO}$ & $\mathrm{Na} 2 \mathrm{O}$ & $\mathrm{k} 2 \mathrm{O}$ & TiO2 & P205 & $\mathrm{MnO}$ & LOI & TOT/C & TOT/S & SUM & $\mathrm{A} / \mathrm{C}+\mathrm{N}+\mathrm{K}$ & $\mathrm{Na} / \mathrm{K}$ \\
\hline kW32 & 48.57 & 35.41 & 1.28 & 0.03 & 0.05 & 1.21 & 8.03 & 0.04 & 0.04 & 0.02 & 5.4 & 0.16 & 0.01 & 100.1 & 3.81 & 0.15 \\
\hline $\mathrm{KW} 18 \mathrm{C}(\mathrm{I})$ & 51.61 & 28.73 & 3.75 & 0.27 & 0.01 & 0.68 & 8.91 & 0.11 & 0.03 & 0.06 & 5.7 & 0.02 & 0.02 & 99.89 & 2.99 & 0.07 \\
\hline KWLMI & 62.94 & 23.65 & 0.61 & 0.09 & 0.07 & 3.87 & 2.7 & 0.03 & 0.06 & 0.06 & 5.5 & 0.06 & 0.01 & 99.61 & 3.56 & 1.43 \\
\hline KW15B & 56.01 & 26.32 & 2.91 & 2.89 & 1.53 & 3.73 & 4.11 & 1.16 & 0.2 & 0.17 & 0.8 & 0.01 & 0.01 & 99.95 & 2.81 & 0.91 \\
\hline KW14 & 55.4 & 27.86 & 2.68 & 0.2 & 0.1 & 0.67 & 8.21 & 0.08 & 0.02 & 0.07 & 4.7 & 0.08 & 0.01 & 100.01 & 3.1 & 0.08 \\
\hline KW12 (I) & 65.46 & 25.29 & 0.04 & 0.02 & 0.08 & 6.08 & 1.4 & 0.01 & 0.29 & 0.01 & 0.4 & 0.02 & 0.01 & 100.03 & 3.35 & 4.34 \\
\hline KW12 (II) & 57.36 & 27.93 & 0.81 & 0.37 & 0.17 & 4.81 & 4.93 & 0.05 & 0.11 & 0.08 & 2.8 & 0.04 & 0.02 & 99.46 & 2.82 & 0.98 \\
\hline KW12B & 59.87 & 26.49 & 0.46 & 0.21 & 0.11 & 7.01 & 3.09 & 0.02 & 0.11 & 0.06 & 2.1 & 0.02 & 0.01 & 99.56 & 2.59 & 2.2 \\
\hline KW12A & 65.41 & 20.89 & 0.6 & 0.27 & 0.04 & 8.04 & 2.61 & 0.02 & 0.07 & 0.09 & 1.7 & 0.01 & 0.01 & 99.75 & 1.95 & 3.3 \\
\hline kW52 & 54.71 & 26.14 & 3.38 & 0.49 & 0.04 & 0.69 & 9.07 & 0.24 & 0.01 & 0.05 & 5.3 & 0.03 & 0.01 & 100.16 & 2.67 & 0.08 \\
\hline KW15A & 75.34 & 15.39 & 0.56 & 0.12 & 0.61 & 2.53 & 2.89 & 0.03 & 0.52 & 0.04 & 1.8 & 0.02 & 0.01 & 99.86 & 2.55 & 1.29 \\
\hline Average & 59.33 & 25.82 & 1.55 & 0.45 & 0.25 & 3.57 & 5.08 & 0.16 & 0.13 & 0.06 & 3.29 & 0.04 & 0.011 & 99.85 & 2.92 & 1.34 \\
\hline SAMPLES (Bishewa) & $\mathrm{SiO}_{2}$ & $\mathrm{Al}_{2} \mathrm{O}_{3}$ & $\mathrm{Fe}_{2} \mathrm{O}_{3}$ & $\mathrm{MgO}$ & $\mathrm{CaO}$ & $\mathrm{Na}_{2} \mathrm{O}$ & $\mathrm{K}_{2} \mathrm{O}$ & $\mathrm{TiO}_{2}$ & P205 & $\mathrm{MnO}$ & LOI & TOT/C & TOT/S & SUM & $\mathrm{A} / \mathrm{C}+\mathrm{N}+\mathrm{K}$ & $\mathrm{Na} / \mathrm{K}(\mathrm{ppm})$ \\
\hline KW1A & 78.11 & 12.49 & 0.71 & 0.04 & 0.11 & 2.82 & 2.8 & 0.01 & 0.1 & 0.02 & 2.8 & 0.01 & 0.01 & 100.01 & 2.18 & 1.00 \\
\hline kW2 & 66.32 & 21.33 & 1.76 & 0.12 & 0.03 & 0.85 & 4.72 & 0.05 & 0.03 & 0.04 & 2.8 & 0.03 & 0.02 & 98.07 & 2.23 & 0.18 \\
\hline KW8A & 72.73 & 15.72 & 0.88 & 0.05 & 0.38 & 5.83 & 2.21 & 0.01 & 0.34 & 0.1 & 1.6 & 0.01 & 0.01 & 99.87 & 1.86 & 2.63 \\
\hline KW $34 \mathrm{C}$ & 71.75 & 17.1 & 0.22 & 0.01 & 0.34 & 4.53 & 2.2 & 0.01 & 0.43 & 0.17 & 2.3 & 0.02 & 0.01 & 99.09 & 2.22 & 2.05 \\
\hline kW3 & 73.68 & 14.26 & 0.38 & 0.05 & 0.03 & 3.75 & 4.87 & 0.02 & 0.05 & 0.01 & 1.2 & 0.02 & 0.01 & 98.33 & 1.64 & 0.26 \\
\hline KW 7 & 67.06 & 17.03 & 3.19 & 0.18 & 0.19 & 4.81 & 2.32 & 0.31 & 0.08 & 0.13 & 3.6 & 0.04 & 0.01 & 97,95 & 2.32 & 2.07 \\
\hline KW19c & 68.71 & 18.65 & 0.95 & 0.12 & 0.05 & 5.94 & 1.36 & 0.07 & 0.16 & 0.05 & 3.8 & 0.05 & 0.01 & 99.88 & 2.54 & 4.4 \\
\hline KW21B & 71.13 & 16.78 & 0.76 & 0.16 & 0.07 & 1.62 & 5.32 & 0.06 & 0.3 & 0.06 & 3.6 & 0.13 & 0.01 & 99.88 & 2.39 & 0.30 \\
\hline KW22B & 64.59 & 19.1 & 2.66 & 0.58 & 0.19 & 2.2 & 3.87 & 0.21 & 0.24 & 0.39 & 5.8 & 0.31 & 0.01 & 99.89 & 3.05 & 0.57 \\
\hline Average & 70.45 & 16.94 & 1.27 & 0.14 & 0.15 & 3.59 & 3.2 & 0.08 & 0.19 & 0.1 & 2.83 & 0.06 & 0.01 & 100 & 2.27 & 1.28 \\
\hline
\end{tabular}

Table 2a: Average trace element composition of Gbugbu pegmatites (ppm)

\begin{tabular}{|c|c|c|c|c|c|c|c|c|c|c|c|c|c|c|c|c|c|c|c|c|c|c|c|c|c|c|c|c|}
\hline tims & m & $\omega$ & po & $2 n$ & $\mathrm{Ni}$ & $c_{0}$ & $\mathrm{~m} n$ & As & & Th & $5 r$ & sb & $8 \mathrm{i}$ & & & \begin{tabular}{|l|}
8 \\
8
\end{tabular} & $\mathrm{w}$ & $2 t$ & $s \mathrm{n}$ & $\mathrm{Be}$ & sc & "w & u & ab & Ta & wb & & $\omega$ \\
\hline anne & & $\begin{array}{c}\text { pop } \\
m\end{array}$ & 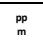 & 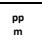 & pom & pop & pomm & pp $\frac{p p}{m}$ & $\mathrm{pemm}$ & $\mathrm{m}$ & 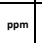 & $\begin{array}{ll}\mathrm{pop} \\
\mathrm{m}\end{array}$ & $\begin{array}{c}\text { pop } \\
\text { mats }\end{array}$ & 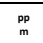 & $\mathrm{ppm}$ & 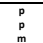 & $\begin{array}{c}\mathrm{pp} \\
\mathrm{m}\end{array}$ & ppm & ${ }_{\mathrm{pom}}$ & $\frac{\mathrm{pmm}}{\mathrm{pm}}$ & ${ }_{\mathrm{pmm}}$ & 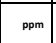 & \begin{tabular}{|l|l|}
$\mathrm{ppm}$ \\
\end{tabular} & pom & ppm & ${ }_{\mathrm{pom}}$ & ${ }_{\mathrm{ppom}}$ & 犃 \\
\hline ${ }^{\mathrm{w} B 3 \mathrm{~A}}$ & & $\begin{array}{l}0.6 \\
\end{array}$ & $\frac{12,}{7}$ & ${ }^{23}$ & $\begin{array}{l}02 \\
\end{array}$ & 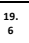 & 160 & ${ }_{3}^{0}$ & 27 & 1 & 74 & $\begin{array}{ll}0.0 \\
8\end{array}$ & $<\infty$ & 0.6 & 1 & \begin{tabular}{|l|l|}
3 \\
5
\end{tabular} & $\mid \begin{array}{c}17 \\
8,7\end{array}$ & ${ }_{a 4}$ & 2594 & \begin{tabular}{|c|}
95 \\
\end{tabular} & 0.3 & 0.611 & 627 & 1655:1.1 & ${ }^{171.7}$ & 10.57 & ${ }_{468}$ & $\begin{array}{l}15 \\
6 \\
6\end{array}$ \\
\hline Kwe28 & ${ }_{0}^{0}$ & ${ }_{1}^{21 .}$ & $\begin{array}{l}82 \\
4\end{array}$ & $\stackrel{96}{92}$ & ${ }_{15}$ & 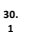 & ${ }_{611}$ & $\frac{1}{1}$ & 37 & 0.4 & ${ }_{37}$ & $\begin{array}{l}0.1 \\
6 \\
6\end{array}$ & 024 & 29 & 1 & ? & $\begin{array}{l}19 \\
4.1\end{array}$ & 69 & ${ }_{14.8}$ & 5 & ${ }_{21} 1$ & $0.46 \mathrm{~b}$ & 21 & 1658 & 1.7 & 20288 & \begin{tabular}{|l|}
.8 \\
\end{tabular} & \\
\hline knv96 & & $\begin{array}{l}5.0 \\
0,0\end{array}$ & $\frac{9.6}{3}$ & $\begin{array}{c}58 \\
88\end{array}$ & 457 & 35 & 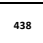 & ${ }_{s}^{1}$ & 0.9 & 95 & $\begin{array}{ll}{ }_{26} & \\
\end{array}$ & $\begin{array}{ll}0.0 \\
5\end{array}$ & 0.11 & $a_{a, 1}$ & 36 & $\frac{8}{8}$ & $\begin{array}{l}20 \\
0\end{array}$ & s9 & 18 & 1 & 8.5 & $\overline{187}$ & \begin{tabular}{|l|l|}
278 \\
\end{tabular} & $9,9,5$ & $\begin{array}{l}1.1 \\
\end{array}$ & 10226 & $\begin{array}{ll}67 \\
\end{array}$ & 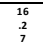 \\
\hline kn338 & ${ }_{i}^{0}$ & 3 & $\begin{array}{ll}160 \\
{ }_{41}\end{array}$ & 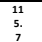 & $428 \mathrm{~s}$ & 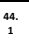 & $\begin{array}{l}205 \\
205\end{array}$ & 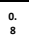 & 09 & $\begin{array}{l}\frac{15.5}{35 .} \\
3\end{array}$ & \begin{tabular}{l|}
81 \\
\end{tabular} & $\begin{array}{ll}0.0 \\
9 \\
9\end{array}$ & 0.04 & 9,1 & 82 & \begin{tabular}{|l|l}
6 \\
2 \\
\end{tabular} & $\begin{array}{l}15 \\
4.6\end{array}$ & 11.8 & 62 & 4 & ${ }_{168}$ & 0.37 & \begin{tabular}{|l|}
1999 \\
3
\end{tabular} & 5228 & \begin{tabular}{ll|}
18 \\
\end{tabular} & $13: 11$ & 8774 & $\begin{array}{c}\frac{20}{20} \\
\text { ond }\end{array}$ \\
\hline knusc & & $\begin{array}{l}0.6,6 \\
3\end{array}$ & 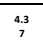 & $\begin{array}{ll}{ }_{s}^{44} \\
s\end{array}$ & 0.5 & $\begin{array}{l}2,2 \\
3 \\
3\end{array}$ & 209 & $\begin{array}{l}0 . \\
8\end{array}$ & 0.8 & 09 & $\begin{array}{lll}{ }^{\circ 0} & \\
\end{array}$ & $\begin{array}{ll}0.00 \\
2\end{array}$ & 0.04 & 1 & 1 & $\begin{array}{ll}4 \\
0\end{array}$ & $\frac{19}{7}$ & 29 & 2335 & 33 & 0.1 & 0.38 & \begin{tabular}{|l}
555 \\
\end{tabular} & ${ }_{1229,7}$ & 1163 & 11833 & 22.6 & 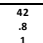 \\
\hline kwss & & $\begin{array}{c}0.4 \\
5\end{array}$ & $\begin{array}{l}3,5 \\
3\end{array}$ & $\begin{array}{l}{ }_{6}^{28} \\
{ }_{6}\end{array}$ & 0.1 & 16 & ${ }_{483}$ & o: & 14as & $a_{2}$ & 22 & $\begin{array}{ll}0.00 \\
6\end{array}$ & 0.11 & 0.2 & ${ }_{4}$ & $\frac{1}{5}$ & $\begin{array}{l}13.6 \\
8.6\end{array}$ & 30.6 & 11.4 & 42 & 0.2 & 4.05 & \begin{tabular}{|l}
21.5 \\
\end{tabular} & 23.6 & 4659 & 236.74 & 2.8 & 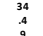 \\
\hline Kwata & & $\begin{array}{l}.09 \\
4 \\
4\end{array}$ & $\begin{array}{l}3.7 \\
1.7\end{array}$ & $\frac{75}{25}$ & 1.1 & 望. & 823 & $\frac{1 .}{7}$ & 4.6 & 13 & ${ }_{53}$ & $\begin{array}{l}0.0 \\
8 \\
8\end{array}$ & 0.16 & o.9 & 4 & & 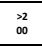 & ${ }_{193}$ & ${ }^{20233}$ & ${ }_{85}$ & ${ }_{41}$ & 2911 & \begin{tabular}{|l|l|}
73,7 \\
\end{tabular} & 2000 & ${ }^{1214}$ & 90065 & ${ }_{512}$ & $\frac{6}{56}$ \\
\hline kNo/6 & & $\begin{array}{c}1.6 \\
6 \\
\end{array}$ & $\begin{array}{l}29 . \\
1\end{array}$ & 3. & 1.4 & 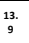 & 398 & : & ${ }_{28}$ & 0.5 & 27 & $\begin{array}{c}0.0 \\
20\end{array}$ & 0.07 & ${ }_{1}$ & so & 9. & 6.1 & 192 & ${ }_{113}$ & 0.5 & ${ }_{129}$ & \begin{tabular}{|l|l}
1261 \\
\end{tabular} & $\begin{array}{l}100 \\
4.4\end{array}$ & 1229 & ${ }_{5486}$ & 6001 & ${ }_{19.08}$ & $\frac{1}{2}$ \\
\hline knows & & $\begin{array}{l}100 \\
27\end{array}$ & $\begin{array}{l}{ }_{81}^{13 .} \\
81\end{array}$ & ss & 156 & 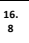 & ${ }_{127}$ & ${ }_{1}$ & 27 & 28 & $\mid{ }_{19}$ & $\begin{array}{c}0.0 \\
0 \\
6\end{array}$ & 0.9 & ${ }_{18}$ & 74 & & $\begin{array}{l}39.9 \\
8\end{array}$ & 81.6 & 492 & 4.7 & 5,53 & \begin{tabular}{|l|l|l}
1024 \\
\end{tabular} & \begin{tabular}{|l|l|}
$\begin{array}{c}970.0 \\
3\end{array}$ \\
\end{tabular} & 2229 & ${ }_{10873}$ & 1998 & 28s1 & $\begin{array}{l}2 \\
5 \\
5\end{array}$ \\
\hline knv9 & & $\begin{array}{l}3.94 \\
5\end{array}$ & $\begin{array}{l}3.4 \\
6\end{array}$ & $\frac{89}{29}$ & 332 & 30 & 5722 & : & $\begin{array}{ll}6.6 & \end{array}$ & 21 & $\begin{array}{ll}4 \\
\end{array}$ & $\begin{array}{ll}0.2 \\
6 \\
6\end{array}$ & ${ }_{145}$ & 81 & 72 & & $\begin{array}{l}566 \\
4\end{array}$ & $\begin{array}{l}291.1 \\
6\end{array}$ & 32 & 2145 & 256 & 2000 & $\begin{array}{ll}2000 \\
0\end{array}$ & (385.5 & ${ }_{20292}$ & 4935 & ${ }_{6552}$ & $\begin{array}{l}111 \\
1.1\end{array}$ \\
\hline kwoo & & $\begin{array}{c}0.6 \\
6 \\
6\end{array}$ & $\begin{array}{l}9,9 \\
5\end{array}$ & $\begin{array}{l}81 \\
.1\end{array}$ & 0.4 & ${ }_{27}$ & $\begin{array}{l}1884 \\
19\end{array}$ & 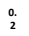 & ${ }_{0.5}$ & 3.1 & 7 & $\begin{array}{c}0.3 \\
7\end{array}$ & 0.08 & 2 & ${ }_{18}^{18}$ & & $\begin{array}{l}0.7 \\
\end{array}$ & 87 & ${ }_{14}$ & 0.2 & 0.1 & 2000 & \begin{tabular}{|l|l}
200 \\
0
\end{tabular} & ${ }_{1595}$ & 90.9 & 2873 & ${ }_{4637}$ & $\begin{array}{ll}0 \\
\end{array}$ \\
\hline $\begin{array}{l}\text { Averag } \\
e\end{array}$ & & $\begin{array}{c}{ }_{4}^{43} \\
5\end{array}$ & ${ }_{4}^{10 .}$ & ${ }_{13}^{13}$ & 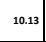 & 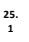 & $\begin{array}{c}10963 \\
6\end{array}$ & $\begin{array}{l}0.8 \\
82\end{array}$ & $3 ., 22$ & 5 & 3,455 & $\begin{array}{l}0.1 \\
1 \\
1\end{array}$ & 029 & $\begin{array}{l}100 \\
98\end{array}$ & 30.45 & & $\begin{array}{l}10 \\
6 \\
6\end{array}$ & $\begin{array}{c}55,3 \\
9\end{array}$ & ${ }^{12733}$ & 27.71 & ${ }_{34}$ & 390.83 & \begin{tabular}{|l|l|}
591. \\
49
\end{tabular} & $\begin{array}{c}56639 \\
09\end{array}$ & $\begin{array}{l}127.722 \\
82\end{array}$ & $\frac{165394}{5}$ & $\begin{array}{r}35.9891 \\
8 \\
8\end{array}$ & ${ }_{1}^{22}$ \\
\hline
\end{tabular}


Table 2b: Average trace element composition of Lema pegmatites (ppm)

\begin{tabular}{|c|c|c|c|c|c|c|c|c|c|c|c|c|c|c|c|c|c|c|c|c|c|c|c|c|c|c|c|c|}
\hline $\begin{array}{c}\text { ELEM } \\
\text { ENT }\end{array}$ & ${ }_{0}^{M}$ & \begin{tabular}{c|}
$c u$ \\
$c u$
\end{tabular} & $\mathrm{pb}$ & $2 n$ & $\mathrm{~N}$ & $c_{0}$ & $\mathrm{Mn}^{\mathrm{mn}}$ & As & u & ${ }^{\mathrm{th}}$ & $s t$ & sb & Bi & $r$ & $a$ & 80 & w & ${ }^{2 t}$ & $\mathrm{sn}_{\mathrm{n}}$ & se & sc & ${ }^{H \prime}$ & u & ab & Ta & No & c & $\omega$ \\
\hline $\begin{array}{c}\text { SAMP } \\
\text { Les }\end{array}$ & $\stackrel{\substack{p p \\
m}}{n}$ & ${ }_{\mathrm{ppm}}$ & ${ }_{\mathrm{ppm}}$ & $\underset{\substack{p_{p} \\
m}}{n^{\prime}}$ & 总 & ${ }^{\mathrm{p} p m}$ & ${ }_{\mathrm{ppm}}$ & $\begin{array}{c}p_{p} \\
m\end{array}$ & $\begin{array}{c}p_{p} \\
m \\
m\end{array}$ & $\mathrm{pem}$ & $\begin{array}{c}\mathrm{pp} \\
\mathrm{m}\end{array}$ & $\underset{\substack{\mathrm{pp} \\
\mathrm{m}}}{ }$ & 总 & $\begin{array}{c}p_{p} \\
m\end{array}$ & $\mathrm{pem}$ & $\mathrm{pem}$ & $\mathrm{ppm}$ & $\stackrel{\substack{p p \\
m}}{m}$ & $\mathrm{ppm}^{\mathrm{pm}}$ & $\begin{array}{c}\mathrm{p}_{\mathrm{p}} \\
\mathrm{m}\end{array}$ & $\underset{\mathrm{p}}{\mathrm{pp}}$ & $\stackrel{\substack{p p \\
m}}{m}$ & $\begin{array}{c}p_{p} \\
m \\
m\end{array}$ & $\mathrm{ppm}$ & $\mathrm{ppm}$ & $\begin{array}{c}\mathrm{pp} \\
\mathrm{m}\end{array}$ & $\stackrel{\substack{p p \\
m}}{ }$ & 然 \\
\hline kN32 & $\begin{array}{l}0.9 \\
13\end{array}$ & ${ }_{1.87}$ & 6.65 & ${ }_{1}^{157}$ & 0.8 & 50.2 & ${ }_{184}$ & 0. & 0.1 & 0.8 & ${ }_{15}$ & $\begin{array}{c}0.4 \\
3\end{array}$ & 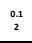 & $\stackrel{0}{3}$ & ${ }_{1}$ & ${ }^{11}$ & 57.7 & ${ }^{1.4}$ & 350.6 & ${ }^{21}$ & ${ }_{3}^{0}$ & 0.3 & 122 & 2000 & $\begin{array}{c}120 . \\
4\end{array}$ & $\begin{array}{l}\text { 157 } \\
81\end{array}$ & $\begin{array}{l}273 \\
{ }_{3}^{2}\end{array}$ & 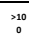 \\
\hline $\begin{array}{c}\text { kw18 } \\
\text { cIII }\end{array}$ & $\begin{array}{l}0 \% \\
06\end{array}$ & $\begin{array}{l}0.57 \\
\end{array}$ & 1.69 & 274 & 19 & 22 & ${ }_{467}$ & ${ }_{i}^{\circ}$ & 0.3 & 0.3 & $=$ & $\begin{array}{c}0.0 \\
2\end{array}$ & 4.1. & $i_{i}$ & 2 & ${ }_{26}$ & 29 & ${ }_{4.4}$ & $\begin{array}{l}1697 \\
\end{array}$ & ${ }_{22}$ & $\begin{array}{l}0 \\
3 \\
\end{array}$ & $\begin{array}{c}0.8 \\
8 \\
\end{array}$ & $\begin{array}{c}121 \\
1 \\
\end{array}$ & 2000 & $\begin{array}{r}260 . \\
4 \\
\end{array}$ & $\begin{array}{r}238 \\
4 \\
\end{array}$ & $\begin{array}{c}1466 \\
5 \\
\end{array}$ & $\begin{array}{c}10 \\
0 \\
0\end{array}$ \\
\hline 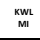 & ${ }_{i 2}^{0}$ & ${ }_{9.04}$ & $\begin{array}{c}39.0 \\
6\end{array}$ & ${ }_{196}$ & 5,5 & ${ }_{93}$ & ${ }_{460}$ & ${ }_{2}^{3}$ & ${ }_{10.1}$ & ${ }^{23}$ & 20 & $\begin{array}{l}15 \\
4,2 \\
4\end{array}$ & $\begin{array}{l}15 \\
{ }^{14} \\
\end{array}$ & $\frac{1}{2}$ & ${ }^{6}$ & ${ }^{31}$ & 83.4 & $\begin{array}{r}16 . \\
6 \\
\end{array}$ & ${ }_{35}$ & $\begin{array}{l}16 \\
{ }_{8}^{16} \\
\end{array}$ & $\begin{array}{c}1,5 \\
5\end{array}$ & $\begin{array}{c}a_{1} \\
2\end{array}$ & $\begin{array}{c}200 \\
{ }_{0}^{200}\end{array}$ & 2000 & 400 & $\begin{array}{r}133 \\
7.76 \\
\end{array}$ & $\begin{array}{c}20 \\
00 \\
000\end{array}$ & $\begin{array}{c}39 . \\
89 \\
\end{array}$ \\
\hline $\begin{array}{c}\text { KW11 } \\
\text { B }\end{array}$ & $\begin{array}{l}{ }_{34}^{\circ} \\
\end{array}$ & ${ }_{4596}$ & 7.37 & $\begin{array}{c}106 \\
5 \\
\end{array}$ & $\begin{array}{l}17 \\
3.5 \\
3\end{array}$ & 63.5 & ${ }_{1451}$ & ${ }_{4}^{1}$ & 0.1 & 0.3 & ${ }_{214}$ & $\frac{0.2}{2}$ & $\begin{array}{l}0.2 \\
0.5 \\
\end{array}$ & $\stackrel{30}{30}$ & 366 & ${ }_{42}$ & 69.2 & ${ }_{3,3}$ & 5.1 & $=$ & $\begin{array}{l}42 \\
{ }_{6}^{2}\end{array}$ & ${ }_{0.3}^{0.3}$ & ${ }_{s}^{143}$ & 7 & 8 & ${ }_{34}^{84}$ & $\begin{array}{c}23 . \\
\text { s. }\end{array}$ & $\begin{array}{l}19.9 \\
19\end{array}$ \\
\hline kN14 & $\begin{array}{l}0.8 \\
08\end{array}$ & 0.84 & 3,55 & $\begin{array}{l}224 \\
{ }_{5}^{2}\end{array}$ & 0.7 & 6.1 & 547 & ${ }_{i}^{0}$ & 0.7 & 0.8 & ${ }^{4}$ & $\stackrel{0.1}{3}$ & $\begin{array}{l}0.7 \\
8 \\
8\end{array}$ & 8 & ${ }^{1}$ & ${ }^{41}$ & 56.1 & 3 & 622 & ${ }_{20}$ & 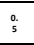 & $\begin{array}{c}0.5 \\
7\end{array}$ & $z^{2}$ & 2000 & 300 & $\begin{array}{l}162 \\
{ }_{28}\end{array}$ & $\begin{array}{c}123 \\
2.3 \\
2\end{array}$ & $\begin{array}{c}10 \\
0 \\
0\end{array}$ \\
\hline $\begin{array}{c}\text { kW12 } \\
\text { (1) }\end{array}$ & $\begin{array}{l}0 . \\
{ }_{i 7}\end{array}$ & ${ }^{1.34}$ & $\begin{array}{c}67.1 \\
8 \\
\end{array}$ & 3.8 & 0.3 & ${ }^{14.2}$ & ${ }_{14}$ & : & 3.3 & 0.3 & ${ }_{61}$ & 1.7 & $\begin{array}{l}0.1 \\
i=1 \\
\end{array}$ & $\begin{array}{l}0 . \\
3\end{array}$ & ${ }_{4}$ & ${ }_{14}$ & ${ }_{1023}$ & 0.5 & 3.8 & ${ }^{\circ}$ & $i_{i}$ & $\begin{array}{c}.0 .0 \\
5 \\
\end{array}$ & ${ }^{65}$ & ${ }_{1453}$ & $\begin{array}{c}295.5 \\
8\end{array}$ & $\frac{7.4}{3}$ & 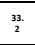 & $\begin{array}{l}35 \\
94\end{array}$ \\
\hline $\begin{array}{c}\text { kw112 } \\
\text { (1) }\end{array}$ & $\begin{array}{l}0 . \\
{ }_{i 1} \\
\end{array}$ & ${ }_{1999}$ & $\begin{array}{c}50.3 \\
5 \\
\end{array}$ & $\stackrel{70}{7}$ & 1.4 & 10.4 & ${ }_{594}$ & ${ }_{3}^{1}$ & ${ }^{283}$ & 3.2 & ${ }^{20}$ & $\begin{array}{l}6,6 \\
3\end{array}$ & $0 ;$ & ; & ${ }^{2}$ & ${ }_{132}$ & ${ }_{87.1}^{87}$ & $\begin{array}{c}12 . \\
6 \\
\end{array}$ & ${ }^{107}$ & ${ }^{21}$ & $z_{2}^{2}$ & ${ }_{34}^{34}$ & $\begin{array}{r}101 \\
7.91 \\
\end{array}$ & ${ }^{2000}$ & ${ }_{410}$ & $\begin{array}{l}119 \\
92 \\
\end{array}$ & ${ }_{7}^{177}$ & $\begin{array}{l}52 . \\
67 \\
\end{array}$ \\
\hline 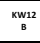 & $\begin{array}{l}{ }_{0} \\
i\end{array}$ & ${ }_{1.52}$ & $\begin{array}{c}43.9 \\
3\end{array}$ & $\begin{array}{c}51 . \\
9 \\
9\end{array}$ & 0.4 & 8.7 & ${ }_{357}$ & $\frac{1}{2}$ & 254 & ${ }_{12}$ & ${ }_{37}$ & $\begin{array}{l}5.0 \\
8\end{array}$ & $\frac{0.5}{8}$ & ${ }_{3}^{0}$ & ${ }_{1}$ & ${ }_{65}$ & ${ }_{228}$ & ${ }_{3}^{10 .}$ & 593 & ${ }_{16}$ & $\frac{1}{4}$ & ${ }^{26}$ & ${ }_{2}^{656}$ & ${ }^{1993}$ & ${ }_{450}$ & 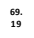 & $\begin{array}{c}527 \\
: 5\end{array}$ & ${ }_{32}^{47}$ \\
\hline$\underset{A}{K W_{12}}$ & $\begin{array}{l}0 \\
i\end{array}$ & ${ }_{1.88}$ & $\underset{6}{21.4}$ & $\begin{array}{c}43 . \\
6.5\end{array}$ & 0.4 & ${ }_{84}$ & ${ }^{717}$ & 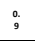 & 2 & 0.4 & ${ }_{15}$ & $\begin{array}{c}18 \\
8\end{array}$ & $\begin{array}{c}0.1 \\
9\end{array}$ & 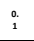 & ${ }_{4}$ & ${ }_{34}$ & 69.9 & 0.6 & ${ }_{38}$ & ${ }_{11}$ & ${ }_{5}^{0}$ & $\begin{array}{c}0.1 \\
6\end{array}$ & $\begin{array}{c}200 \\
{ }_{0}^{200}\end{array}$ & 2000 & ${ }_{933}$ & $\begin{array}{l}29 . \\
75\end{array}$ & $\begin{array}{l}107 \\
0.7\end{array}$ & $\begin{array}{c}52 . \\
81\end{array}$ \\
\hline kws2 & $\begin{array}{l}0 . \\
16\end{array}$ & ${ }_{26}$ & ${ }_{3,43}$ & $\begin{array}{l}100 \\
{ }_{1}^{100}\end{array}$ & 0.7 & 58 & ${ }^{429}$ & ${ }_{8}^{1}$ & 0.8 & 0.2 & 1 & $\begin{array}{l}0.1 \\
6\end{array}$ & $\frac{12}{2}$ & ${ }_{3}^{0}$ & ${ }^{1}$ & 6 & ${ }_{42.6}$ & 24 & ${ }_{3394}$ & ${ }_{20}$ & $\begin{array}{l}2.2 \\
8\end{array}$ & 0.6 & $\begin{array}{c}211 \\
3\end{array}$ & ${ }^{1630.1}$ & 905 & $\begin{array}{l}263 \\
{ }_{02}^{263}\end{array}$ & $\begin{array}{c}247 \\
3\end{array}$ & ${ }_{100}$ \\
\hline $\begin{array}{c}\text { KW15 } \\
\mathrm{A}\end{array}$ & $\begin{array}{l}0.1 \\
{ }_{21}\end{array}$ & 284 & $\begin{array}{r}67.4 \\
8 \\
\end{array}$ & $\begin{array}{r}29 . \\
8\end{array}$ & ${ }^{23}$ & ${ }_{17.2}$ & ${ }_{253}^{253}$ & $\begin{array}{l}0 . \\
6\end{array}$ & 2 & 0.9 & ${ }_{54}$ & $\begin{array}{c}.1 .1 \\
8\end{array}$ & $\begin{array}{r}<0 \\
4\end{array}$ & 2 & 79 & $\begin{array}{c}\text { 148. } \\
9\end{array}$ & 7.4 & $\begin{array}{c}190 \\
4 \\
\end{array}$ & ${ }_{56}^{56}$ & 0.7 & ${ }_{86}^{16}$ & $\begin{array}{c}21,5 \\
9.5 \\
\end{array}$ & $\begin{array}{r}186 \\
7.35 \\
\end{array}$ & $322 \mathrm{~A}$ & 97.6 & $\begin{array}{r}199 \\
.2 \\
\end{array}$ & $\begin{array}{r}28 . \\
54 \\
\end{array}$ & ${ }^{0.8}$ \\
\hline $\begin{array}{c}\text { Avera } \\
\mathrm{ge}\end{array}$ & $\begin{array}{l}0.5 \\
\text { is }\end{array}$ & ${ }_{7.58}$ & $\begin{array}{r}28.3 \\
7\end{array}$ & $\begin{array}{c}114 \\
36 \\
\end{array}$ & $\begin{array}{c}178 \\
08 \\
\end{array}$ & 17881 & 497.54 & $\begin{array}{c}18 \\
18\end{array}$ & $\begin{array}{c}505 \\
8 \\
\end{array}$ & 0.97 & 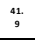 & $\begin{array}{c}15 . \\
51 \\
51\end{array}$ & $\begin{array}{r}20 \\
8\end{array}$ & $\begin{array}{l}3.3 \\
3\end{array}$ & ${ }_{41,12}$ & $\begin{array}{c}50.0 \\
8\end{array}$ & 60.68 & $\begin{array}{c}22 . \\
s \\
\end{array}$ & ${ }_{11.46}$ & $\begin{array}{c}28 . \\
24 \\
\end{array}$ & ; & $\begin{array}{c}21 . \\
114 \\
\end{array}$ & $\begin{array}{c}7.99 \\
0.94 \\
\end{array}$ & $\begin{array}{r}14643 \\
4\end{array}$ & $\begin{array}{r}229 \\
63\end{array}$ & $\begin{array}{l}125 \\
83 \\
\end{array}$ & $\begin{array}{l}205 \\
{ }_{64}^{25} \\
\end{array}$ & $\begin{array}{c}31 . \\
69\end{array}$ \\
\hline
\end{tabular}

Table 2c: Average trace element composition of Lema pegmatites ppm)

\begin{tabular}{|c|c|c|c|c|c|c|c|c|c|c|c|c|c|c|c|c|c|c|c|c|c|c|c|c|c|c|c|c|}
\hline 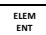 & $\begin{array}{ll}M \\
0\end{array}$ & $\omega$ & pb & $2 n$ & Nit & $c_{0}$ & $\mathrm{Mn}_{\mathrm{n}}$ & As & u & th & $s t$ & $\mathrm{sb}$ & $\mathrm{Bi}$ & $r$ & $\alpha$ & $\mathrm{Ba}$ & w & $z r$ & $s_{n}$ & Be & $\mathrm{sc}$ & ${ }^{\mathrm{Ht}}$ & u & मв & Ta & 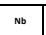 & ${ }^{\circ}$ & $\sigma_{0}$ \\
\hline samp & $\mathrm{p}_{\mathrm{m}}^{\mathrm{pp}}$ & $\underset{\substack{p p \\
m}}{p}$ & $\mathrm{p}_{\mathrm{m}}^{\mathrm{pp}}$ & pop & 鼠 & ${ }^{\mathrm{ppm}}$ & ${ }_{\mathrm{ppm}}$ & $p_{m}^{p_{p}}$ & ${ }_{\mathrm{pmm}}$ & ${ }_{\mathrm{ppm}}$ & ${ }_{\mathrm{ppm}}$ & ${ }_{\mathrm{ppm}}$ & $\begin{array}{c}\mathrm{pp} \\
\mathrm{m}\end{array}$ & $\underset{\substack{p p \\
m}}{p}$ & ppm & ppm & ${ }_{\mathrm{ppm}}$ & ${ }_{\mathrm{m}}^{\mathrm{p}}$ & 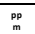 & pom & $\substack{p \\
m}^{p_{1}}$ & $\mathrm{pmm}$ & 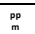 & $\mathrm{ppm}$ & ppm & ${ }_{\mathrm{ppm}}$ & ${ }_{\mathrm{ppm}}$ & ${ }_{\mathrm{pom}}$ \\
\hline кми & $\begin{array}{l}{ }_{28}^{0} \\
28\end{array}$ & 0.97 & $\begin{array}{l}3.7 \\
8\end{array}$ & 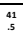 & $i_{j}$ & 237 & 129 & 0.7 & 0.9 & 0.2 & 6 & 0.07 & 0.8 & 0.1 & ${ }_{\triangle 1}$ & 8 & 1952 & 13 & 15 & , & $i_{i}$ & 0.45 & $\begin{array}{l}16.6 \\
3\end{array}$ & $\begin{array}{l}1175 \\
25\end{array}$ & 120 & ${ }_{12.1}$ & ${ }_{1313}$ & 4654 \\
\hline kw2 & 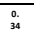 & 539 & 1.9 & $\frac{87}{67}$ & $\frac{1}{15}$ & 249 & 308 & 1.2 & ${ }_{14}$ & 1.2 & 5 & 0.1 & 0.5 & 0.5 & 3 & 40 & 174 & 9.6 & $\frac{92}{98}$ & ${ }_{12}$ & 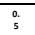 & 1066 & 69.9. & $\begin{array}{c}158 \\
s_{5}\end{array}$ & 822 & \begin{tabular}{l|l}
1450 \\
4
\end{tabular} & ${ }_{281}$ & 2100 \\
\hline kwen & $\begin{array}{l}{ }_{20}^{0} \\
{ }_{3}\end{array}$ & 1.72 & $\begin{array}{l}8.6 \\
3.6\end{array}$ & $\begin{array}{l}25 \\
.25 \\
\end{array}$ & $\begin{array}{ll}0.0 \\
s\end{array}$ & 227 & 503 & 0.2 & 39 & ${ }_{45}$ & 17 & 0.55 & 15 & 4 & 4 & 6 & ${ }_{198}$ & $\begin{array}{l}45.5 \\
6\end{array}$ & $\frac{11}{8}$ & 46 & 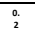 & 376 & $\begin{array}{l}83 . \\
9\end{array}$ & 31.1 & 855 & $\begin{array}{c}270,3 \\
9\end{array}$ & ${ }_{157}$ & 20.07 \\
\hline $\begin{array}{c}\text { kw34 } \\
c_{c}\end{array}$ & $\begin{array}{l}0_{52} \\
52\end{array}$ & 9.23 & $\frac{9.6}{6}$ & $\frac{14}{14}$ & $\begin{array}{l}3 . \\
4_{4}^{3}\end{array}$ & ${ }_{168}$ & ${ }_{1432}$ & 1.9 & 19 & 28 & 38 & ${ }_{0.08}$ & 0.3 & 0.5 & 1 & 261 & 1022 & ${ }_{3}^{10 .}$ & $\begin{array}{l}5 . \\
4\end{array}$ & , & $i_{i}$ & 0.87 & ${ }_{28}$ & ${ }_{167}$ & 289 & 3728 & 0.7 & 23.1 \\
\hline $\mathrm{kW}_{3}$ & $\begin{array}{l}{ }_{24} \\
24\end{array}$ & 0.05 & $\begin{array}{l}33 . \\
57\end{array}$ & $\begin{array}{l}10 \\
.1\end{array}$ & 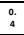 & 209 & 44 & 0.9 & 02 & 0.2 & 75 & 0.15 & $\overbrace{4}^{<0}$ & 0.3 & ${ }^{{ }^{4} 1}$ & 282 & 189.2 & 54 & 20 & 3 & ${ }_{3}^{1}$ & 0,4 & 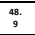 & $\begin{array}{l}4055 \\
3 \\
3\end{array}$ & ${ }_{44}$ & 2855 & 90 & ${ }^{2045}$ \\
\hline $\mathrm{Rw}^{\mathrm{kw}}$ & $\bar{g}_{97}^{2}$ & $\begin{array}{l}3288 \\
57\end{array}$ & $\frac{311}{n ! n}$ & $\frac{201}{20}$ & 15 & 13 & 971 & 29 & 1.7 & 6.4 & s11 & 0.6 & $\begin{array}{l}18 . \\
98\end{array}$ & $\begin{array}{l}20 . \\
4\end{array}$ & $\begin{array}{l}10 \\
\end{array}$ & ${ }_{127}$ & 729 & ${ }_{24}^{11}$ & 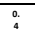 & 4 & $\begin{array}{l}2 \\
5\end{array}$ & 0.5 & 68 & $\begin{array}{l}124 . \\
\frac{124}{8}\end{array}$ & 5.6 & 22 & 73 & 20.98 \\
\hline kw19 & 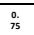 & 521 & $\begin{array}{l}171 \\
71\end{array}$ & 30 & ; & 233 & 304 & 0.7 & 0.8 & ${ }_{1.4}$ & 31 & 0.03 & $\begin{array}{l}0.3 \\
3\end{array}$ & 6 & 49 & $\begin{array}{l}\text { 19at. } \\
7\end{array}$ & 52 & $\begin{array}{l}45.5 \\
3\end{array}$ & ${ }_{78}$ & 15 & ${ }_{81}^{0}$ & 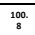 & $\begin{array}{l}6.00 \\
0.6\end{array}$ & $\begin{array}{l}194 . \\
3\end{array}$ & $\begin{array}{c}127,7 \\
5\end{array}$ & 392 & 2824 & 13 \\
\hline $\mathrm{K}_{\mathrm{B} W 21}$ & $\begin{array}{ll}0.0 \\
57\end{array}$ & $\begin{array}{l}226 \\
2\end{array}$ & $\begin{array}{l}{ }_{34}^{24} \\
34\end{array}$ & $\frac{65}{.65}$ & 17 & $\begin{array}{l}449 \\
\end{array}$ & 3651 & 0.6 & ${ }_{1.1}$ & 3.4 & 18 & $<<02$ & $\frac{02}{8.2}$ & 85 & 193 & 10.4 & 11.9 & 26 & 2 & 11.8 & $\begin{array}{l}0 \\
99\end{array}$ & 208 & $\begin{array}{l}35 . \\
T\end{array}$ & 150 & 2951 & 5.4 & 5.6 & 99 \\
\hline $\mathrm{KW}_{\mathrm{B}} \mathrm{k22}$ & ${ }_{0}^{0}$ & 23.2 & $\begin{array}{l}24.4 \\
9\end{array}$ & 63 & $\begin{array}{l}15 \\
4\end{array}$ & 23 & ${ }_{2892}$ & is & 6.1 & 25 & 39 & 4.5 & 28 & 5.6 & 153 & 402 & 1425 & $\begin{array}{l}34 . \\
4\end{array}$ & 69 & 26 & ${ }^{45}$ & 1.2 & $\begin{array}{ll}100 \\
8\end{array}$ & $\begin{array}{l}477 . \\
4\end{array}$ & 89 & 27 & 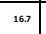 & 12.3 \\
\hline $\begin{array}{l}\text { Avera } \\
\mathrm{ge}\end{array}$ & $e_{i_{3}}$ & $\frac{4,1}{7}$ & ${ }_{91}^{171}$ & $\begin{array}{l}39 \\
{ }_{3}\end{array}$ & 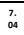 & 23.88 & 1137.11 & $\begin{array}{c}100 \\
11\end{array}$ & 2 & 251 & 8222 & 0.17 & ${ }_{5}^{28}$ & $\begin{array}{l}13 \\
62\end{array}$ & 24.58 & $\begin{array}{l}{ }_{102}^{102} \\
01\end{array}$ & ${ }^{1212}$ & 29 & $\begin{array}{l}3.11 \\
.6\end{array}$ & $\begin{array}{c}13,3 \\
6\end{array}$ & ${ }_{64}^{0}$ & $\begin{array}{l}14 a 4 \\
3\end{array}$ & $\begin{array}{l}n, 1 \\
n .7\end{array}$ & $\begin{array}{l}4_{770} \\
78\end{array}$ & 63,6 & sat11 & ${ }_{43326}$ & 17771 \\
\hline
\end{tabular}

Table 2d: Elemental ratios of selected trace elements of Gbugbu and Lema pegmatites (ppm)

\begin{tabular}{|c|c|c|c|c|c|c|c|c|c|c|c|c|c|c|c|c|c|c|c|c|c|c|c|c|}
\hline tats & ${ }_{\mathrm{B}}^{\mathrm{KW} 33}$ & kwasc & 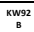 & ${ }^{\mathrm{kn} w 3}$ & אWMg & 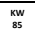 & knusen & kw76 & KN25 & kwas & ким9 & $\begin{array}{ll}\text { Averag } \\
\text { ef }\end{array}$ & kw32 & Kwwigc & 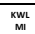 & 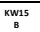 & KW14 & 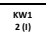 & $\begin{array}{c}\mathrm{kw1} \\
2(1)\end{array}$ & א火火128 & $\mathrm{K}_{\mathrm{A}}^{\mathrm{KA}}$ & kws & kwisa & $\begin{array}{l}\text { Averea } \\
\text { se }\end{array}$ \\
\hline $\mathrm{k} / \mathrm{Rb}$ & 0.002 & 0.019 & 0.019 & 0.006 & 0.003 & $\begin{array}{c}0.09 \\
2\end{array}$ & 0,002 & 0.025 & 0.005 & 0.226 & 0.009 & 0.005 & 0.004 & 0.004 & 0,0001 & 0.587 & 0.004 & \begin{tabular}{|l|l|l|}
0 \\
\end{tabular} & $\begin{array}{c}0.000 \\
2\end{array}$ & 0.002 & 0.000 & 0.006 & 0.008 & 0.003 \\
\hline $\mathrm{k} / \mathrm{Ba}$ & 0.0106 & 0.033 & 0.002 & 0.005 & 0.092 & $\begin{array}{c}0.14 \\
5\end{array}$ & 0.019 & 0.0938 & 0.013 & 0.067 & 0.007 & 0.014 & 0.370 & 0.343 & 0.087 & 0.098 & 0.200 & 0.100 & $0.0,3$ & 0.048 & 0.077 & $\begin{array}{l}1.512 \\
\end{array}$ & 0.019 & 0.101 \\
\hline $\begin{array}{l}\mathrm{R} 0 / \mathrm{s} \\
\end{array}$ & $\begin{array}{r}2182 \\
6 \\
6\end{array}$ & 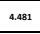 & 3827 & 6.8255 & $\begin{array}{l}30,74 \\
3 \\
3\end{array}$ & $\begin{array}{c}107 \\
3 \\
3\end{array}$ & 37.736 & 4,552 & $\begin{array}{c}11,73 \\
2\end{array}$ & 9.625 & 22,796 & 15977 & $\begin{array}{l}\begin{array}{l}1333 \\
33\end{array} \\
\end{array}$ & 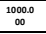 & $\begin{array}{c}68866 \\
6 \\
6\end{array}$ & 0.033 & 50000 & 2382 & $\begin{array}{l}689 \\
66 \\
6\end{array}$ & 525519 & $\begin{array}{r}1333 \\
33\end{array}$ & 1630.1 & 7.081 & 39948 \\
\hline $\mathrm{k} / \mathrm{s}$ & 0.079 & ${ }_{0.328}$ & 0.285 & 0.090 & 0.162 & $\begin{array}{l}0.77 \\
5\end{array}$ & 0.071 & 0.159 & 0.039 & 0.074 & 0.029 & 0.083 & 0.029 & 0.061 & 0.001 & 0.175 & 0.067 & 0.042 & $\begin{array}{l}0.000 \\
6\end{array}$ & 0.006 & 0.002 & 0.037 & 0.010 & 0.017 \\
\hline $2 / / H$ & 7213 & 15,000 & $\begin{array}{l}3.1 .55 \\
1 \\
1\end{array}$ & $\begin{array}{ll}31.99 \\
2\end{array}$ & 7.632 & $\begin{array}{c}7.55 \\
6 \\
6\end{array}$ & 6.632 & 0.113 & 0.502 & 0.146 & 0.044 & 0.142 & 4 & 5.000 & 4029 & $\begin{array}{l}10.00 \\
0\end{array}$ & 5,263 & $\begin{array}{l}10.00 \\
0\end{array}$ & $\begin{array}{l}429 \\
4\end{array}$ & 3389 & 3.5.50 & 4,000 & 0.867 & 10.54 \\
\hline The & 0.961 & 0.009 & 0.006 & 0.012 & 0.590 & $\begin{array}{l}3.36 \\
1 \\
1\end{array}$ & 0.067 & 8993 & 2,332 & 4,662 & $\begin{array}{ll}129,85 \\
7\end{array}$ & $\begin{array}{l}1.98 \\
\end{array}$ & 20877 & 8.979 & 4.996 & 0.116 & 5.3 .38 & 28991 & $\begin{array}{c}4.70 \\
7\end{array}$ & ${ }^{7.166}$ & ${ }^{1.335}$ & 2.124 & 13.189 & 3,784 \\
\hline Toll & 1.590 & 0.008 & 0.107 & 0.137 & 0.983 & $\begin{array}{l}1966 \\
88\end{array}$ & 1.339 & 0.913 & ${ }_{0.549}$ & 0.533 & 0.316 & 0.763 & 0.763 & 1.092 & 2990 & o949 & 1.899 & $\frac{39.81}{2}$ & $\begin{array}{l}356 \\
856\end{array}$ & 6.504 & 3.366 & 0.0349 & 0,990 & 18225 \\
\hline 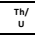 & 2,2700 & 9250 & 0.095 & 0.059 & 0.898 & $\begin{array}{l}3.52 \\
4 \\
4\end{array}$ & 3538 & 5,500 & 0.964 & 0.314 & 0.161 & 0.683 & 0.125 & 1.000 & 4391 & 0.333 & 0.875 & $\begin{array}{l}11000 \\
0\end{array}$ & 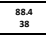 & $\frac{211,66}{7}$ & 5,000 & 4,000 & 2222 & 52.244 \\
\hline 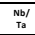 & 0.592 & 1299.929 & 9,937 & 72833 & 1.017 & $\begin{array}{ll}0.50 \\
8\end{array}$ & 0.797 & 1.996 & 1820 & $\begin{array}{l}1877 \\
\end{array}$ & 3.611 & ${ }_{1.31}$ & ${ }_{1.311}$ & $\begin{array}{l}0.916 \\
\end{array}$ & 0.334 & ${ }_{1054}$ & 0.541 & 0.025 & ${ }_{0.28}^{028}$ & 0.54 & 0.319 & 2906 & 20041 & 0.548 \\
\hline
\end{tabular}

Table 2e: Elemental ratios of selected trace elements of Bishewa pegmatites (ppm)

\begin{tabular}{|c|c|c|c|c|c|c|c|c|c|}
\hline Ratios & KW2 & KW8A & KW34C & KW3 & KW 7 & KW19C & KW21B & KW22B & Average \\
\hline $\mathrm{K} / \mathrm{Rb}$ & 0.003 & 0.071 & 0.132 & 0.010 & 0.019 & 0.007 & 0.035 & 0.008 & 0.007 \\
\hline $\mathrm{K} / \mathrm{Ba}$ & 0.118 & 0.368 & 0.008 & 0.017 & 0.018 & 0.010 & 0.512 & 0.010 & 0.023 \\
\hline $\mathrm{Rb} / \mathrm{Sr}$ & 317.000 & 1.829 & 0.439 & 6.471 & 0.244 & 6.268 & 8.333 & 12.241 & 5.726 \\
\hline $\mathrm{K} / \mathrm{Cs}$ & 0.168 & 0.141 & 3.143 & 0.054 & 0.032 & 0.048 & 0.950 & 0.232 & 0.074 \\
\hline $\mathrm{Zr} / \mathrm{Hf}$ & 9.057 & 12.128 & 11.839 & 12.273 & 224.800 & 0.449 & 0.125 & 28.667 & 2.055 \\
\hline $\mathrm{Ta} / \mathrm{W}$ & 0.472 & 0.430 & 0.283 & 0.023 & 0.077 & 24.567 & 2.480 & 0.625 & 0.525 \\
\hline $\mathrm{Ta} / \mathrm{Nb}$ & 0.567 & 0.499 & 0.775 & 0.154 & 0.255 & 3.259 & 5.465 & 3.296 & 1.175 \\
\hline $\mathrm{Th} / \mathrm{U}$ & 1.167 & 0.867 & 0.679 & 1.000 & 0.266 & 0.571 & 0.324 & 2.440 & 0.797 \\
\hline $\mathrm{Nb} / \mathrm{Ta}$ & 1.764 & 2.002 & 1.290 & 6.489 & 3.929 & 0.307 & 0.183 & 0.303 & 0.851 \\
\hline
\end{tabular}

